\title{
The Human Penis Is a Genuine Immunological Effector Site
}

\begin{abstract}
Alexis Sennepin ${ }^{1,2,3}$, Fernando Real ${ }^{1,2,3}$, Marine Duvivier $^{1,2,3}$, Yonatan Ganor $^{1,2,3}$, Sonia Henry ${ }^{1,2,3}$, Diane Damotte ${ }^{4}$, Marc Revol ${ }^{5}$, Sonia Cristofari ${ }^{5}$ and Morgane Bomsel,2,3*

1 Laboratory of Mucosal Entry of HIV-1 and Mucosal Immunity, Department of Infection, Immunity and Inflammation, Cochin Institute, INSERM, Paris, France, ${ }^{2}$ CNRS, UMR8104, Paris, France, ${ }^{3}$ Paris Descartes University, Sorbonne Paris Cité, Paris, France, ${ }^{4}$ Anatomy and Pathological Cytology Service, GH Cochin-Saint Vincent de Paul, Paris, France, ${ }^{5}$ Plastic Surgery Service, Saint Louis Hospital, Paris, France
\end{abstract}

The human penis is a main portal of entry for numerous pathogens, and vaccines able to control resulting infections locally are highly desirable. However, in contrast to the gastrointestinal or vaginal mucosa, the penile immune system and mechanisms inducing a penile immune response remain elusive. In this descriptive study, using multiparametric flow cytometry and immunohistochemistry, we characterized mucosal immune cells such as B, T, and natural killer (NK) cells from the urethra, fossa, and glans of human adult penile tissues. We show that memory $\mathrm{B}$ lymphocytes and $\mathrm{CD} 138^{+}$plasma cells are detected in all penile compartments. $\mathrm{CD} 4^{+}$and $\mathrm{CD} 8^{+} \mathrm{T}$ lymphocytes reside in the epithelium and lamina propria of the penile regions and have mostly a resting memory phenotype. All penile regions contain CD56 dim NK cells surface expressing the natural cytotoxicity receptor NKp44 and the antibody-dependent cell cytotoxicity receptor CD16. These cells are also able to spontaneously secrete pro- and anti-inflammatory cytokines, such as IL-17 and IL-22. Finally, CCR10 is the main homing receptor detected in these penile cells although, together with CCR3, CCR6, and CCR9, their expression level differs between penile compartments. Unlike antigen-presenting cells which type differ between penile regions as we reported earlier, urethral, fossa, and glans content in immune B, T, and NK cells is comparable. However, median values per each analysis suggest that the glans, containing higher number and more activated NK cells together with higher number of terminally differentiate effector $\mathrm{CD} 8^{+} \mathrm{T}$ cells, is a superior effector site than the urethra and the fossa. Thus, the human penis is an immunologically active tissue containing the cellular machinery required to induce and produce a specific and effective response against mucosal pathogens. It can therefore be considered as a classic mucosal effector site, a feature that must be taken into account for the elaboration of efficient strategies, including vaccines, against sexually transmitted infections.

\section{Keywords: mucosal immune system, male genial tract, mucosal immunity, B cells, mucosal vaccines}

\section{INTRODUCTION}

Sexually transmitted infections (STIs) are a main health issue worldwide (1), and the male genital tract is a portal of entry for numerous sexually transmitted pathogens, including viral and bacterial pathogens, such as human papilloma virus (HPV) (2), Chlamydia trachomatis (3) or Neisseria gonorrhoeae (4). Furthermore, we and others also demonstrated that human immunodeficiency virus type 1 (HIV-1) targets the penile foreskin and urethra (5-10). 
To reduce or prevent these STIs, vaccine strategies targeting the penis are crucially needed. Accordingly, initial HIV-1 vaccine studies were able to induce HIV-1 specific mucosal antibodies, although non-neutralizing, in the male genital mucosa (11). Furthermore, exposed seronegative (ESN) men harbor high urethral concentrations of HIV-1-specific IgA induced by nonprotected insertive sexual intercourses with seropositive female partners (12). These studies indicate that the human male genitals, as in other species (13), are effector sites. However, the lack of progress in developing vaccines to stimulate local protection in the penis is mainly due to the lack of information on the penile immune system.

The human penis consists of four different regions: (i) the foreskin, a stratified keratinized epithelium, with a highly keratinized outer face and a less keratinized inner one facing the glans (8), (ii) the glans, a stratified keratinized epithelium; (iii) the fossa navicularis (referred to here as fossa), a stratified nonkeratinized epithelium, and (iv) the urethra, a pseudo-stratified non-keratinized epithelium $(6,8)$. The penis susceptibility to STI depends largely on the intrinsic characteristics of the mucosal immune system of each of these regions.

Innate and adaptive immune responses contribute both to protection at mucosal surfaces (14). The mucosal innate immune system is the first line of defense against mucosal pathogens and comprises numerous components including epithelial barriers, antimicrobials peptides (15), pattern recognition receptors, such as toll-like receptors (TLRs) (16), and inflammatory immune cells, such as natural killer (NK) cells and neutrophils, which are mainly involved in apoptosis of infected cells and phagocytosis, respectively. Antigen-presenting cells that include macrophages, Langerhans cells (LCs) and dendritic cells (DCs), participate in innate immune responses, as well as the initiation of adaptive immune responses by presenting antigens to lymphocytes. Such adaptive immune responses, which take place in a second step following the innate immune responses, are pathogen specific and involve two arms, namely, the humoral response coordinated predominantly by B cells, with or without $\mathrm{CD} 4^{+} \mathrm{T}$ cells help, and the cellular response driven by cytotoxic $\mathrm{T}$ cells.

Penile mucosal immune cells and their interactions with STI have been little studied due to the difficulty in obtaining human tissues, whereas the foreskin immunity is better understood particularly in the context of HIV-1 infection. Hence, we showed that HIV-1 targets first LCs during sexual transmission of HIV-1 in non-circumcised men (7), providing an explanation at the cellular level to the reduction by $>60 \%$ of HIV-1 acquisition in men provided by removal of the foreskin following circumcision. Circumcision also protects men efficiently against other STI including HPV and herpes simplex virus (HSV)-2 (17). In agreement with an only partial protection to STI resulting from circumcision, other penile regions are targeted by STIs. Indeed, HIV-1 also targets macrophages in the penile urethra as we reported $(10)$. Other studies $(5,6,18)$ have reported on the immune cell content of the penis using qualitative morphological analyses, although a detailed phenotype and the role of these mucosal immune cell populations were not assessed. To fill this gap, we provide here an in-depth characterization of
$\mathrm{B}, \mathrm{T}$, and NK cells present in the different penile regions, namely, the urethra, fossa, and glans mucosae, a crucial prerequisite for the elaboration of efficient preventive and vaccinal strategies against STIs.

\section{MATERIALS AND METHODS}

\section{Ethical Statement}

The study was performed according to local ethical regulations, following approval by the local ethical committee [Comité de Protection des Personnes (CPP) Île-de-France XI, approval no. 11016]. Written informed consent was provided by all study participants.

\section{Tissues}

Whole penile tissues were obtained from 39 individuals undergoing elective gender reassignment surgery at the Saint Louis Hospital in Paris, France (mean age 38 years, range 19-58 years). Hormonal treatment was stopped 2 months before surgery, and all patients lacked history of STIs during the 6 months before the surgery. Tissues were transported to the laboratory immediately after surgery in phosphate-buffered saline (PBS) supplemented with $20 \mu \mathrm{g} / \mathrm{ml}$ gentamicin (Gibco) and used within the next $2 \mathrm{~h}$.

\section{Single Cell Suspensions}

Urethra, fossa, and glans were first mechanically separated, each region cut into $8 \mathrm{~mm} \times 8 \mathrm{~mm}$ pieces, and the underlying fat and muscle removed. To prevent denaturation or removal of cell surface molecules by dispase/trypsin enzymes that are routinely used to separate the epidermal and dermal compartments, cells were directly extracted from the tissues by collagenase type IV digestion $(2 \mathrm{mg} / \mathrm{ml}$, Sigma) in the presence of DNAse I (200 U/ml, Roche) for $2 \mathrm{~h}$ at $37^{\circ} \mathrm{C}(7,9)$. After enzyme inactivation with RPMI medium containing $10 \%$ fetal bovine serum (FBS, Gibco), tissue pieces were vortexed for $30 \mathrm{~s}$. The resulting cell suspensions were filtered through $100 \mu \mathrm{m}$ nylon cell strainers (Falcon) and centrifuged for $5 \mathrm{~min}$ at $450 \mathrm{~g}$.

\section{Flow Cytometry}

Cells were resuspended in PBS-2\% FBS, transferred to a 96 roundbottom well plate $\left(10^{6}\right.$ cells/well) and labeled with indicated combinations of antibodies (Table S1 in Supplementary Material) or matched isotype control antibodies (Table S2 in Supplementary Material) for $30 \mathrm{~min}$ at $4^{\circ} \mathrm{C}$. Cells were washed twice in PBS-2\% FBS and fixed with Cytofix/Cytoperm solution (BD Biosciences) for $15 \mathrm{~min}$ at room temperature.

Data were acquired, with an LSRII cytometer (BectonDickinson, Cochin CYBIO platform) and analyzed with Kaluza Software (Beckman-Coulter). As shown on Figure 1, penile lymphocytes were identified based on their forward and side scatter, after a cell-doublet exclusion step. Next, lymphocytes were identified as $\mathrm{CD} 45^{+}$cells, and immune cell populations were defined according to their phenotypic characteristics, namely, $\mathrm{CD}^{-}{ }^{-} \mathrm{CD} 19^{+}$for $\mathrm{B}$ cells, $\mathrm{CD}^{+} \mathrm{CD}^{+}{ }^{+}$for $\mathrm{CD} 4^{+} \mathrm{T}$ cells, $\mathrm{CD}^{+} \mathrm{CD}^{+}$ for $\mathrm{CD}^{+} \mathrm{T}$ cells, and $\mathrm{CD} 3{ }^{-} \mathrm{CD} 56^{+}$or $\mathrm{CD}^{+} \mathrm{CD} 56^{+}$for $\mathrm{NK}$ and NKT cells, respectively. Finally, phenotypes, activation status, 


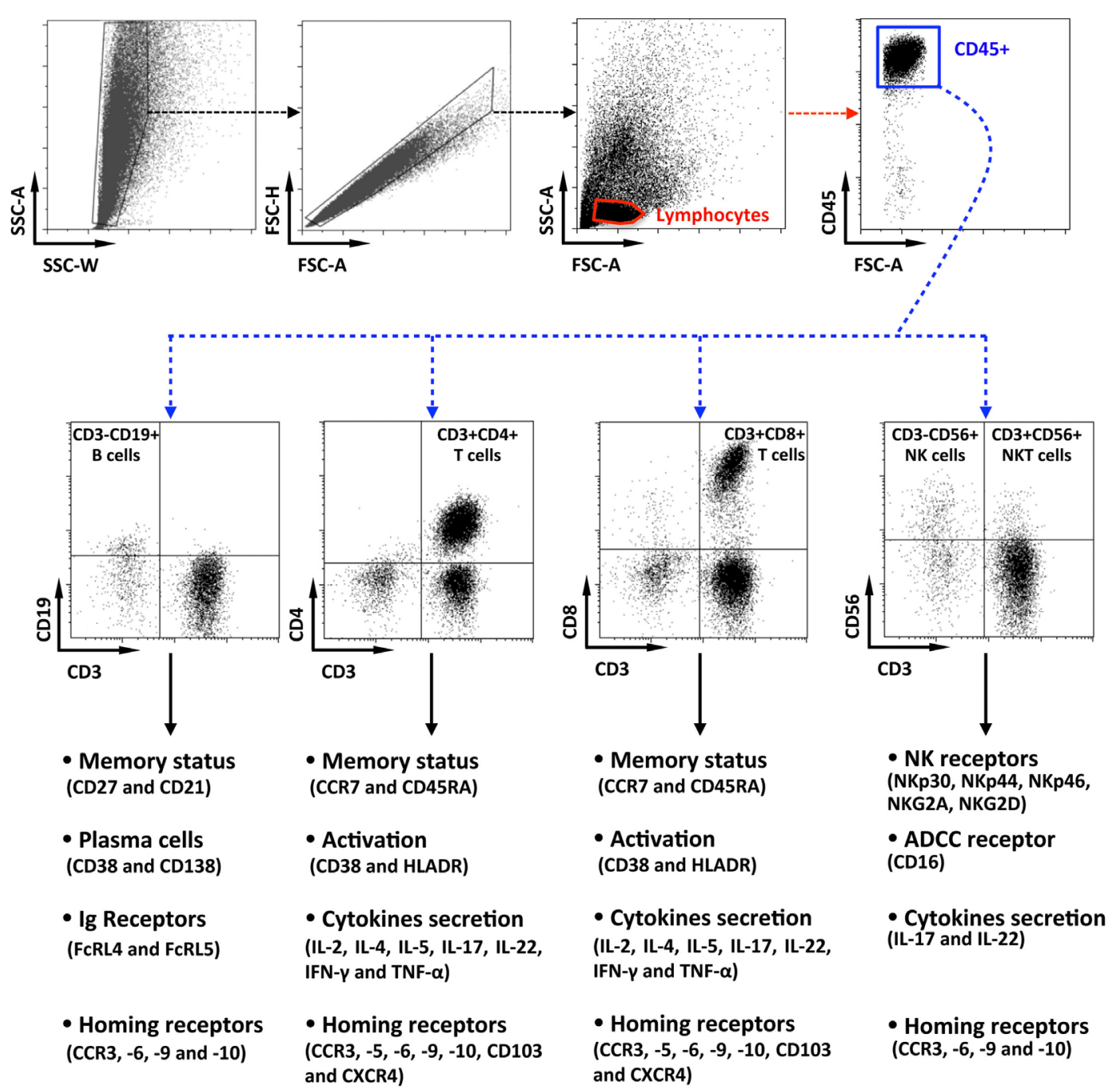

FIGURE 1 | Flow cytometry gating strategy for the characterization of penile cells. Representative dot plots of penile single cells suspensions studied by multiparametric flow cytometry, showing the gating strategy. After cell-doublet exclusion (SSC-W/SSC-A and FSC-A/FSC-H dot plots), lymphocytes were gated based on their forward (FSC-A) and side (SSC-A) scatter (lymphocytes gate). After gating on CD45+ lymphocytes, penile immune cell populations were defined as CD3 ${ }^{-}$CD19 ${ }^{+} \mathrm{B}$ cells, CD3 ${ }^{+} \mathrm{CD} 4^{+} \mathrm{T}$ cells, CD3 ${ }^{+} \mathrm{CD} 8^{+} \mathrm{T}$ cells, CD3-CD56 ${ }^{+}$natural killer cells, and CD3 ${ }^{+} \mathrm{CD} 56^{+} \mathrm{NKT}^{-}$cells. Each population was then studied for their phenotypes, activation status, function as well as for the presence of potential homing receptors according to the strategy indicated in the figure.

as wells as functions, were evaluated for each population as indicated.

\section{Intracellular Cytokine Staining}

Penile cells were plated in $500 \mu \mathrm{l}$ culture medium (RPMI medium containing $10 \% \mathrm{FBS}$ ) for $5 \mathrm{~h}$ at $37^{\circ} \mathrm{C}$ in the presence of Brefeldin A $(5 \mu \mathrm{g} / \mathrm{ml}$, Sigma). Cells were washed twice in PBS-2\% FBS and labeled with anti-CD4, anti-CD8 and anti-CD56 antibodies or matched isotype control antibodies for $30 \mathrm{~min}$ at $4^{\circ} \mathrm{C}$. Cells were washed twice in PBS-2\% FBS and fixed with Cytofix/Cytoperm solution (BD Biosciences) for $15 \mathrm{~min}$ at room temperature. Cells were washed with PermWash buffer (BD Biosciences) and stained for intracellular IL-2, IFN- $\gamma$, TNF- $\alpha$, IL-4, IL-5, IL-17, and IL-22 for $30 \mathrm{~min}$ at $4^{\circ} \mathrm{C}$ using appropriate antibodies (Table $\mathrm{S} 1$ in Supplementary Material) or corresponding isotype control antibodies (Table S2 in Supplementary Material), diluted in PermWash buffer.

Data were acquired with an LSRII cytometer (BectonDickinson, Cochin CYBIO platform) and analyzed following the gating strategy shown in Figure 1 with Kaluza Software (Beckman-Coulter) as indicated before.

\section{Immunohistochemistry}

Urethra, fossa, and glans tissue pieces were fixed with PBS-4\% paraformaldehyde, embedded in paraffin and serially sectioned at $4 \mu \mathrm{m}$. Immunohistochemistry was performed as we previously described $(7,10)$ using appropriate antibodies (Table S3 in Supplementary Material), and the LSAB2 System HRP (Abcam) labeling kit, and visualized with diaminobenzidine (Dako) or histogreen (Abcys) peroxidase substrates according to the 
manufacturer's recommendations. Image acquisition was performed with an OlympusBX63F microscope (Cochin IMAG'IC platform), and images were analyzed using the open-access GNU Image Manipulation Program (The GIMP Team).

\section{Cytokines/Chemokine Quantification}

Urethra, fossa, and glans tissue pieces ( $5 \mathrm{~mm} \times 3 \mathrm{~mm} \times 1 \mathrm{~mm}$ ) were lysed in $500 \mu \mathrm{l}$ of PBS- $0.2 \%$ SDS containing a protease inhibitor cocktail (1:1,000 dilution, Roche), disrupted using a Qiagen TissueRuptor. Resulting cell lysates were stored at $-80^{\circ} \mathrm{C}$. Cytokines, namely, MCP-1/CCL2, MIP-3 $\alpha /$ CCL20, RANTES/CCL5, TRAIL/TNFSF10, MCP-4/CCL13， IL-4, IL-13, CTACK/CCL27, and Eotaxin/CCL11, were quantified using the Luminex technology (LXSAHM-12 Kit, R\&D) on a Bio-Plex 200 (Bio-Rad, Cochin CYBIO platform) according to the manufacturer's recommendations. Furthermore, CCL25 and CCL28 were quantified using the Quantikine immunoassay (DTK00 and DCC280 kits, respectively, R\&D) according to the manufacturer's recommendations.

\section{Statistical Analysis}

Statistical analysis was performed with Prism6 software (GraphPad). For flow cytometry analyses, tissues of the various penile regions did not always originate from the same individual. The results are expressed as median, followed by the $95 \%$ confidence interval $(95 \% \mathrm{CI})$. For comparing the immune cell populations between the different penile compartments, although such statistics have to be taken cautiously due to the limited number of tissue samples, the non-parametric Kruskal-Wallis test was used. Pairwise comparisons were performed by the non-parametric Mann-Whitney $U$-test. $p$-Values $<0.05$ were considered significant. ${ }^{\star} p<0.05,{ }^{* *} p<0.01$, and ${ }^{* *} p<0.001$.

\section{RESULTS}

\section{Memory B Cells Are Present in All Penile Regions}

$B$ cells are an important population of adaptive immunity driving the humoral response by producing antibodies after antigenic stimulation. Characterization of their phenotypes is a fundamental prerequisite for the elaboration of efficient vaccine strategies against STIs.

Therefore, the presence of B lymphocytes, defined by the expression of the pan leukocyte marker CD45 and CD19, but lack of CD3, was determined in each penile compartment by multiparametric flow cytometry (Figures 2A,B). $\mathrm{CD}^{-} \mathrm{CD} 19^{+}$ B cells represented $0.5-3.0 \%$ of CD45 cells, with median [95\% CI range]: $3.2 \%$ [2.8-3.45] in the urethra, $2.3 \%$ [1.7-2.8] in the fossa, and $1.3 \%[0.7-2.0]$ in the glans.

Next, co-expression of CD21 and CD27 was used to characterize the four B cell subsets (19), namely, $C D 21^{+} \mathrm{CD} 27^{-}$naïve $\left(\mathrm{B}_{\mathrm{N}}\right)$, $\mathrm{CD} 21^{+} \mathrm{CD} 27^{+}$resting memory $\left(\mathrm{B}_{\mathrm{RM}}\right), \mathrm{CD} 21^{-} \mathrm{CD} 27^{+}$activated memory $\left(\mathrm{B}_{\mathrm{AM}}\right)$, and $\mathrm{CD} 21^{-} \mathrm{CD} 27^{-}$tissue-like memory $\left(\mathrm{B}_{\mathrm{TLM}}\right)$ $B$ cells (Figures $2 \mathrm{C}, \mathrm{D}$ ).

The major B cell subset was $\mathrm{B}_{\mathrm{TLM}}$ in all three penile compartments. Although the frequency of $\mathrm{B}_{\text {TLM }}$ was similar between urethra (53.2\% [43.3-63.1]) and fossa (64.5\% [55.5-73.5]), it was higher in the glans (74.4\% [70.9-77.8]). In addition, while $\mathrm{B}_{\mathrm{AM}}$ and $\mathrm{B}_{\mathrm{RM}}$ were both present in urethra (32.5\% [27.9-37] and $31.9 \%$ [29.1-34.7], respectively) and fossa (37.4\% [31.4-43.4], and $5.9 \%[3.7-8.1], p=0.0286$ vs urethra, respectively), $\mathrm{B}_{\mathrm{AM}}$ were significantly less abundant (19.3\% [15.4-23.2] $p=0.0236$ relative to the urethra), and $\mathrm{B}_{\mathrm{RM}}$ were almost absent $(1.3 \%$ [0.85-1.85], $p=0.0286$ relative to the urethra) in the glans. Finally, $\mathrm{B}_{\mathrm{N}}$ were present at similar proportions in urethra $(10.5 \%$ [8.6-12.4]), fossa (9.6\% [7-12.2]), and glans (7.2\% [5.8-8.5]).

Altogether, memory $\mathrm{B}$ cells $\left(\mathrm{B}_{\mathrm{TLM}}>\mathrm{B}_{\mathrm{AM}}\right)$ predominate over resting memory/naive $\mathrm{B}$ cells in the penis.

\section{Penile B Cells Express the IgA Fc Receptor-Like 4 (FcRL4) and the IgG Fc Receptor-Like 5 (FcRL5)}

The FcRL4 and FcRL5 were recently described as receptors for IgA and IgG, respectively (20). FcRL4 is expressed on $\mathrm{B}_{\mathrm{TLM}}$ cells that lack the classical CD27 memory B cell marker, and FcRL4 ${ }^{+}$ $\mathrm{B}$ cells localize at the subepithelial and marginal zones of mucosal lymphoid tissues. FcRL4 ${ }^{+} \mathrm{B}$ cells express switched immunoglobulins that have undergone variable region somatic mutations and secrete high levels of IgG but also IgA in response to stimulation with $\mathrm{T}$ cell cytokines, but not following B-cell receptor (BCR) cross-linking (21). FcRL5 is also expressed specifically on CD27 negative B cells, and FcRL5 cross-linking induces B cell proliferation and surface IgA and IgG expression, suggesting that FcRL5 participates in the expansion and development of antigen-primed $\mathrm{B}$ cells in physiological conditions (22). Thus, we determined the surface expression of these two receptors on penile $B$ cells by flow cytometry. The frequency of FcRL4 $4^{+} \mathrm{B}$ cells was higher in the urethra (20.3\% [16.8-23.9]) compared with the fossa $(10.6 \%$ [8.2-12.9]) and glans (5.7\% [3.1-8.2]) (Figure 2E, left panel). By contrast, the less abundant FcRL5 ${ }^{+} \mathrm{B}$ cells were equally present in all three regions $[(1.3 \%[0.6-1.9]) ;(2.8 \%[1.8-3.7])$; and $(2.5 \%$ [1.3-3.7]) for urethra, fossa and glans, respectively] (Figure 2E, right panel).

\section{The Penis Contains Plasma Cells (PCs)}

The capacity of penile B cells to secrete antibodies was inferred from the presence of $\mathrm{CD} 38^{+} \mathrm{CD} 138^{+}$mucosal PCs among B cell populations in penile tissues. PCs were present in all penile regions representing less than $5 \%$ of total B cells in urethra $(5 \%$ $[4.5-5.6])$, fossa $(4.2 \%[3.3-5.0])$, and glans (1.8\% [0.9-2.6]) (Figure 2F). The frequency of PCs was higher in the urethra and fossa compared with glans.

Staining of the tissues for CD138/syndecan-1 expression followed by immunohistochemistry (Figure 2G) indicated that all penile regions contained $\mathrm{CD} 138^{+} \mathrm{PCs}$ in the lamina propria. In line with the flow cytometry results, the densities of PCs in the urethra and the fossa were greater than in the glans. The expression of syndecan-1 by keratinocytes precluded the specific detection of PCs in the penile epithelia using this marker.

Altogether, all three penile compartments, and especially the urethra, contain B cells of which small amounts are PCs. Penile 
B cells are mainly memory cells, with either a tissue-like memory or an activated memory phenotype. Expression of FcRL4 (and to a lesser extent FcRL5) and syndecan-1 together with their lamina propria localization are indicative of the presence of antibodysecreting PCs.
Penile CD4 ${ }^{+}$and $\mathrm{CD}^{+}{ }^{+} \mathrm{T}$ Cells Are Mainly Resting Effector Memory (EM) Cells

$\mathrm{CD}^{+}$and $\mathrm{CD}^{+} \mathrm{T}$ cells are key players in the adaptive immune response. To identify their presence and profile in penile tissues,
A

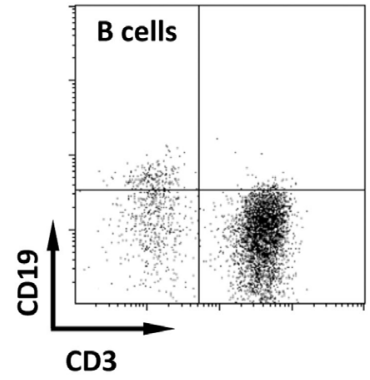

C

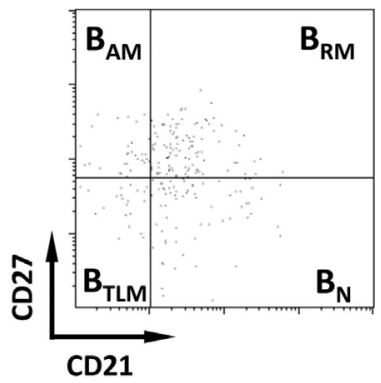

E

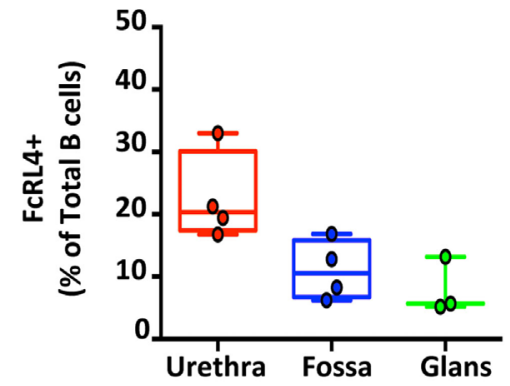

G

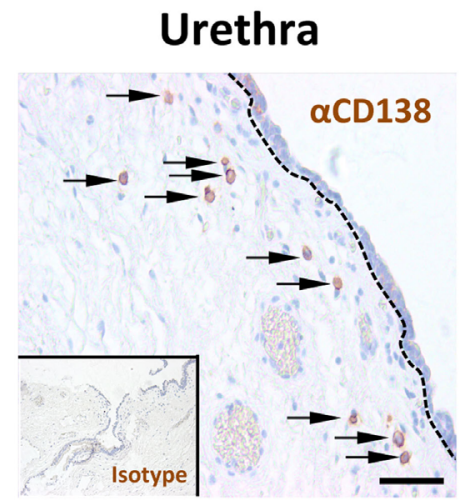

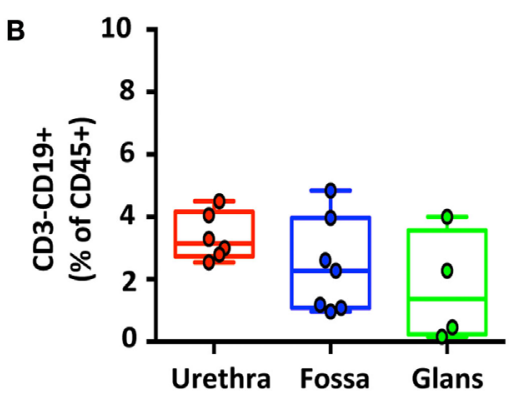

D
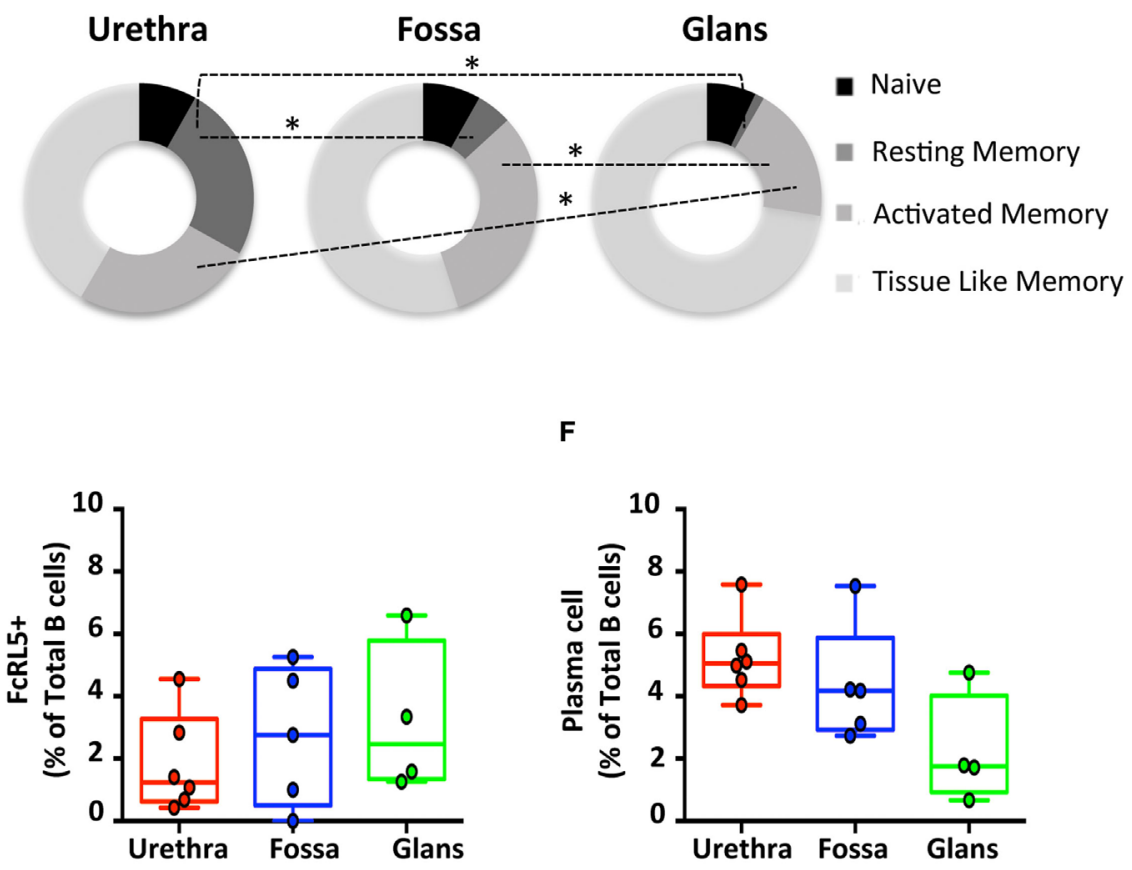

Fossa

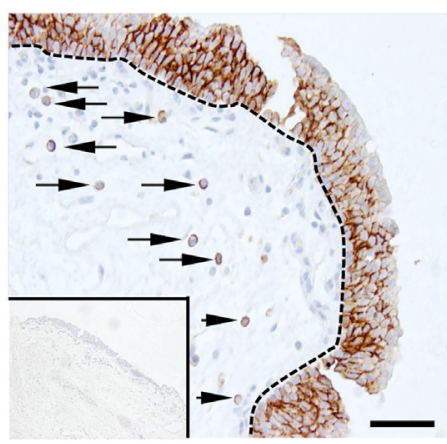

Glans

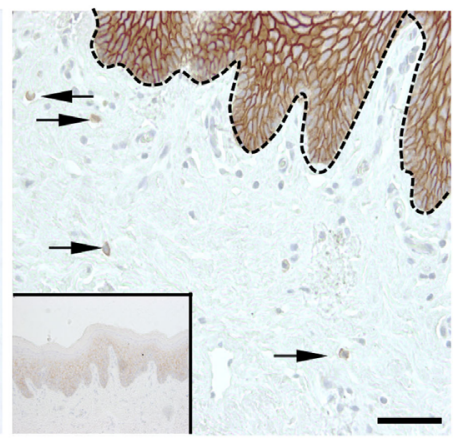

FIGURE 2 | Continued 


\section{FIGURE 2 | Continued}

Frequency and phenotype of B cells subsets and plasma cells (PCs) distribution in the penile mucosa. (A) Representative dot plot and (B) box-and-whisker plots of total B cells proportions in urethra, fossa, and glans. B cells were characterized by a CD45+CD3-CD19+ phenotype $[n=6$, 7 , and 4 different donors for urethra, fossa, and glans, respectively; mean age 43 years (range: 24-58)]. (C) Representative dot plot and (D) proportions of memory B cell subsets in the different parts of penile mucosa $[n=6,5$, and 4 different donors for urethra, fossa, and glans, respectively; mean age 39 years (24-56)]. Memory phenotype was defined as follows: naive $\left(B_{N}, C D 21^{+} \mathrm{CD} 27^{-}\right)$, resting memory $\left(B_{\mathrm{RM}}, C D 21^{+} \mathrm{CD} 27^{+}\right)$, activated memory $\left(\mathrm{B}_{\mathrm{AM}}, \mathrm{CD} 21^{-} \mathrm{CD} 27^{+}\right)$, and tissue-like memory cells $\left(\mathrm{B}_{\mathrm{TLM}}\right.$, CD21-CD27-) after gating on CD45+CD3-CD19+ B cell population. (E) Proportions of FCRL4+ [left panel, $n=4,4$, and 3 different donors for urethra, fossa, and glans, respectively; mean age 43 years (24-58)] and FCRL5+ [right panel, $n=6,5$, and 4 different donors for urethra, fossa, and glans, respectively; mean age 43 years (24-58)] cells in the total CD45+CD3-CD19+ B cell population in urethra, fossa, and glans. (F) Proportions of PCs in penile tissues $[n=6,5$, and 4 different donors for urethra, fossa, and glans, respectively; mean age 39 years (24-56)] after gating on $\mathrm{CD}_{4} 5^{+} \mathrm{CD} 3^{-} \mathrm{CD} 19^{+} \mathrm{CD} 38^{+} \mathrm{CD} 138^{+}$population.

(G) Immunohistochemistry analysis of CD138+ PCs (brown), by comparison with isotype control (inset), in urethra, fossa, and glans [representative of $n=5$ different donors for each tissue; mean age 41 years (26-54)]. Cells were stained with an anti-CD138 antibody or a rabbit lgG isotype control and revealed using diaminobenzidine peroxidase substrate (brown staining). Scale bar $=50 \mu \mathrm{m}$. All box-and-whisker plots represent minimum-to-maximum values, and each point corresponds to one donor. Statistical analyses were performed first by the Kruskal-Wallis test; pairwise comparisons were performed by the Mann-Whitney U-test. ${ }^{\star} p<0.05,{ }^{\star \star} p<0.01$, and ${ }^{\star \star \star} p<0.001$.

the frequency of cells co-expressing CD3/CD4 and CD3/CD8 was determined amongst $\mathrm{CD} 45^{+}$population (Figures $3 \mathrm{~A}, \mathrm{C}$, respectively). In the urethra, $\mathrm{CD}^{+} \mathrm{T}$ cells predominated over $\mathrm{CD}^{+} \mathrm{T}$ cells, representing 58.6\% [55.5-61.8] and 39.7\% [37.1-42.2] of $\mathrm{CD}^{+} \mathrm{T}$ cells, respectively. In fossa and glans, $\mathrm{CD}^{+} \mathrm{T}$ cells were present in equivalent proportions, and significantly lower than in the urethra (52\% [48.4-55.6], $p=0.0219$ and 51.5\% [47.3-55.7], $p=0.0303$, respectively). $\mathrm{CD}^{+} \mathrm{T}$ cells were equally present in all penile regions (see above for the urethra, $43.9 \%$ [39.5-48.2] and 47.5\% [45-50] of $\mathrm{CD}^{+}$cells for fossa and glans, respectively) (Figures 3B,D). Tissue distribution of $\mathrm{CD}^{+}$and $\mathrm{CD}^{+} \mathrm{T}$ cells was also evaluated by immunohistochemistry following co-labeling with anti-CD3 (blue staining) and anti-CD8 (brown staining) antibodies. Hence, $\mathrm{CD}^{+} \mathrm{T}$ cells co-express CD3 and CD8 (blue/ brown staining), whereas $\mathrm{CD} 4{ }^{+} \mathrm{T}$ cells expressed $\mathrm{CD} 3$ but not CD8 (blue staining only) (Figure 3E). Matched isotypes served as negative control (data not shown). In the urethra, fossa, and glans, both $\mathrm{CD}^{+}$and $\mathrm{CD}^{+} \mathrm{T}$ cells localized in the lamina propria, close to the mucosal epithelium, whereas the majority of cells within the epithelial compartment were $\mathrm{CD}^{+} \mathrm{T}$ cells. However, it cannot be excluded that some of the cells detected by this technique also express $\mathrm{T}$ cell markers on their surface such as NKT cells.

Next, T cell maturation was assessed using CD45RA and CCR7 to distinguish four $\mathrm{T}$ cell subsets (23), namely, CD45RA ${ }^{+} \mathrm{CCR}{ }^{+}$ naive $\left(\mathrm{T}_{\mathrm{N}}\right), \mathrm{CD} 4 \mathrm{RA}^{-} \mathrm{CCR} 7^{+}$central memory $\left(\mathrm{T}_{\mathrm{CM}}\right)$, $\mathrm{CD}^{2} 5 \mathrm{RA}^{-} \mathrm{CCR}^{-}{ }^{-}$effector memory $\left(\mathrm{T}_{\mathrm{EM}}\right)$, and CD45RA ${ }^{+} \mathrm{CCR}^{-}$ effector $\left(\mathrm{T}_{\mathrm{E}}\right) \mathrm{T}$ cells. CD4 ${ }^{+} \mathrm{T}$ cells (Figures 3F,G, upper panel) mainly harbored a $\mathrm{T}_{\mathrm{EM}}$ phenotype in all penile regions, consisting of 92.1\% [89.8-94.4] in the urethra, 95.1\% [93.5-96.7] in fossa, and $88.8 \%$ [84.6-92.9] in glans. $\mathrm{CD}^{+} \mathrm{T}_{\mathrm{N}}, \mathrm{CD}^{+} \mathrm{T}_{\mathrm{CM}}$, and $\mathrm{CD} 4^{+}$ $\mathrm{T}_{\mathrm{E}}$ represented each less than $5 \%$ of the total $\mathrm{CD} 3^{+} / \mathrm{CD} 4^{+} \mathrm{T}$ cell population. Similar phenotypes applied to the $\mathrm{CD} 3^{+} / \mathrm{CD} 8^{+} \mathrm{T}$ cells (Figure 3G, lower panel) that mainly consisted of $\mathrm{T}_{\mathrm{EM}}$ with equivalent frequencies of $69.5 \%$ [63.4-75.7] and 70.0\% [62.7-77.3], in the urethra and fossa, but significantly dropping to $35.5 \%$ [29.8-41.2] in the glans ( $p=0.0159$ vs urethra and fossa). $\mathrm{T}_{\mathrm{E}}$ constituted an important glans $\mathrm{CD}^{+}$subset (53.5\% [49.8-57.1] of $\mathrm{CD}^{+} \mathrm{T}$ cells), whereas in the urethra and fossa, $\mathrm{CD}^{+} \mathrm{T}_{\mathrm{E}}$ dropped significantly (27.9\% [22.1-33.9] and 24.8\% [16.7-32.9], $p=0.0079$ and 0.0156 vs the glans, respectively).
Intermediate memory $\mathrm{T}$ cells $\left(\mathrm{T}_{\mathrm{IM}}\right)$ were next quantified based on CD27 expression in the CCR7 negative memory T cells population (Figure $3 \mathrm{H}$ ). $\mathrm{T}_{\mathrm{IM}}$ represented around $5 \%$ of the memory population of both $\mathrm{CD}^{+}$and $\mathrm{CD} 8^{+} \mathrm{T}$ cells (Figure 3I), with $5.2 \%$ [4.5-5.9] and 4.5\% [2.5-6.6] in the urethra, 5.1\% [3.8-6.5] and $3 \%$ [2.5-3.6] in fossa, and 6.6\% [4.7-8.6] and 4.7\% [4.1-5.4] in glans.

Last, $\mathrm{T}$ cell activation, defined by co-expression of HLA-DR and CD38, was assessed (Figure 4A). In the urethra and fossa, $\mathrm{CD} 4^{+} \mathrm{T}$ cells exhibited a resting phenotype, as activated cells coexpressing CD38 and HLA-DR represented only 8.2\% [6.7-9.7] and $2.8 \%$ [1.2-4.4] (Figure 4B, left panel). In the glans, activated cells were significantly lower and practically absent, representing only $0.5 \%$ [0.47-0.58] ( $p=0.008$ vs urethra and fossa). Penile $\mathrm{CD}^{+} \mathrm{T}$ cells, as $\mathrm{CD}^{+} \mathrm{T}$ cells, had also a resting phenotype (Figure 4B, right panel, 10.2\% [7.2-13.2]; 5.6\% [2.7-8.5]; 1.3\% $[1.0-1.6]$ in the urethra, fossa, and glans, respectively. $p=0.0079$ for urethra vs glans and fossa vs glans).

\section{Resident Memory T Cells Form a Minor T Cell Subset in All Penile Regions}

Memory T cells, particularly $\mathrm{CD} 8^{+}$cells that can remain in tissues without recirculation through the blood (24), are referred to as resident memory cells, and can be characterized by the expression of CD69, L-selectin (CD62L) and CD103 ( $\alpha \mathrm{E} \beta 7$ integrin). Both $\mathrm{CD}^{+}$and $\mathrm{CD}^{+} \mathrm{T}$ cells poorly expressed CD69 (Figures 4C,D) and CD62L (Figures 4E,F). By contrast, T cells expressing CD103 dominated in the CD8 ${ }^{+}$subset, with $16.7 \%$ [10.3-23.1] in the urethra, $8.5 \%$ [1.5-15.5] in the fossa, and 6.1\% [0.4-11.8] in the glans, compared with only around $5 \%$ expression in the $\mathrm{CD}^{+}$subset in all penile regions $(4.6 \%$ [3-6.2]; 4.1\% [1.7-6.6]; $3.7 \%[0.6-6.8]$ in the urethra, fossa, and glans, respectively) (Figures 4G,H), although their distribution was very heterogeneous between individuals.

Overall, $\mathrm{CD} 4^{+}$and $\mathrm{CD} 8^{+} \mathrm{T}$ cells are equally present in all penile tissue regions and harbor a resting phenotype. Whereas $\mathrm{CD} 4^{+}$ $\mathrm{T}$ cells are mostly (>90\%) EM cells, $\mathrm{CD}^{+} \mathrm{T}$ cell subsets include mainly EM cells but also effector cells, especially in the glans. Furthermore, the higher expression of $\mathrm{CD} 103$ by $\mathrm{CD}^{+}$relative to $\mathrm{CD}^{+} \mathrm{T}$ cells translates into a higher epithelial $\mathrm{CD}^{+} \mathrm{T}$ cells distribution than that of $\mathrm{CD} 4^{+} \mathrm{T}$ cells, although both subsets are equally present in the lamina propria. 


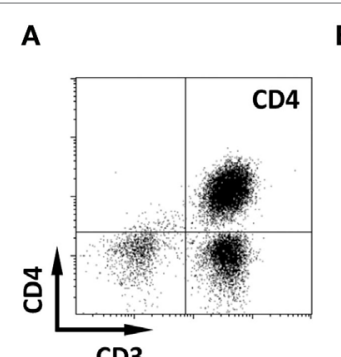

CD3
B

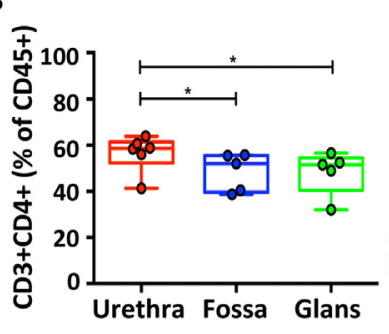

C

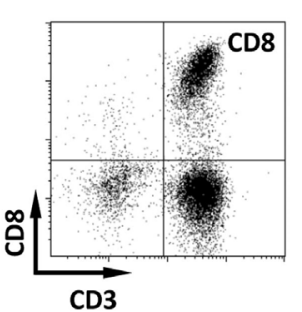

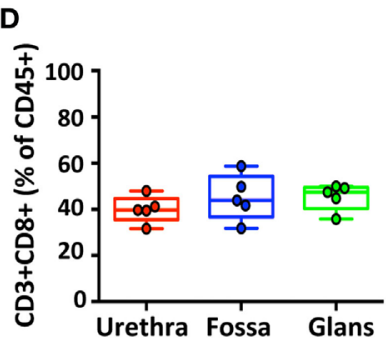

E

Urethra

Fossa

Glans

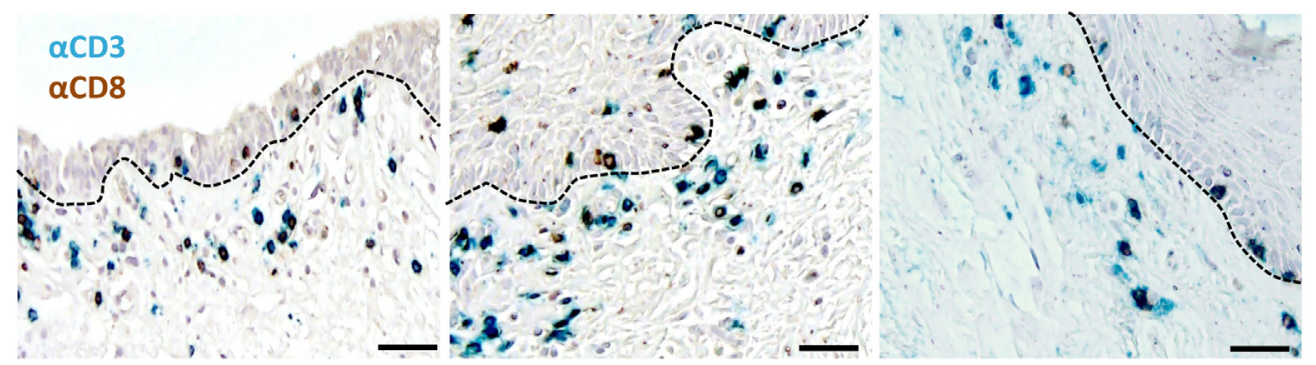

$\mathbf{F}$

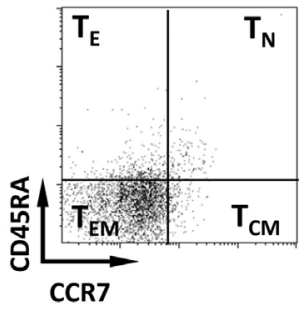

H

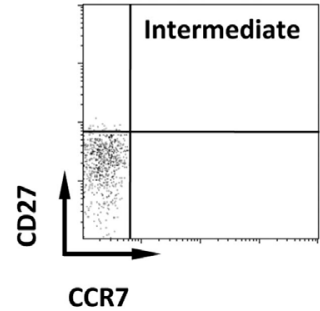

G Urethra Fossa

Fossa Glans
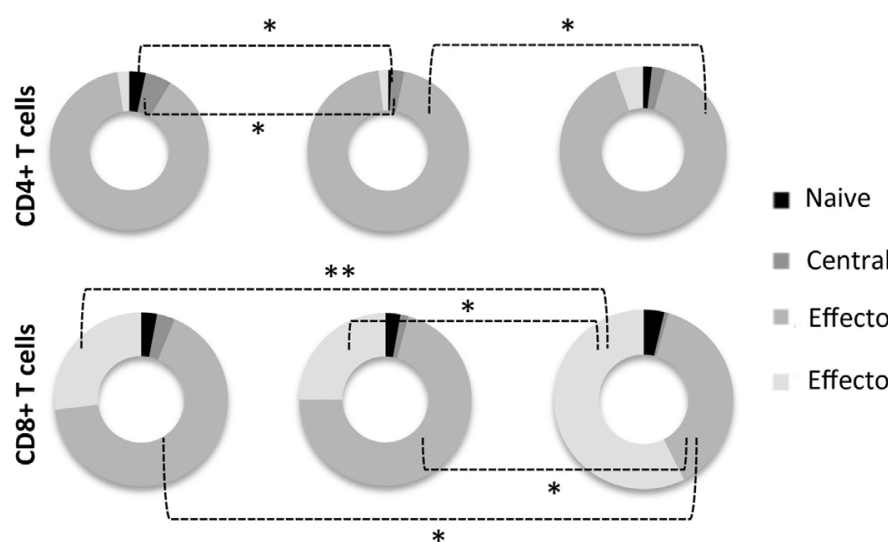

- Central Memory

In Effector Memory

Effector

I
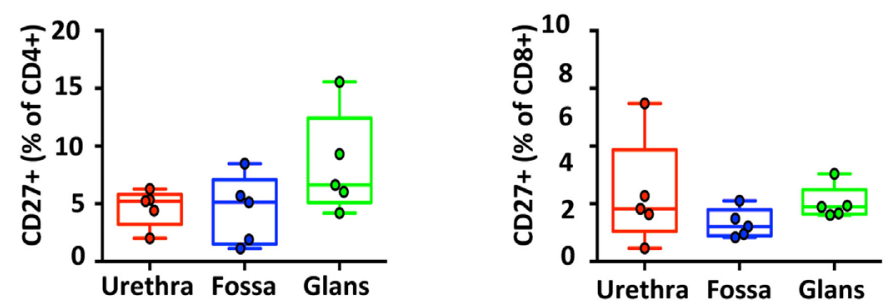

FIGURE 3 | Characterization of penile $C D 4^{+}$and $C D 8^{+} T$ cells. (A,C) Representative dot plots and (B,D) box-and-whisker plots of total $C D 45^{+} C D 3^{+} C D 4^{+}$ $\mathrm{T}(\mathbf{A}, \mathbf{B})$ and $C D 45^{+} \mathrm{CD} 3^{+} \mathrm{CD} 8^{+} \mathrm{T}(\mathbf{C}, \mathbf{D})$ cells (referred to as $\mathrm{CD} 4^{+}$and $\mathrm{CD} 8^{+} \mathrm{T}$ cells, respectively) proportions in urethra, fossa, and glans $[n=6,5$, and 5 different donors for urethra, fossa, and glans, respectively; mean age 37 years (range: 22-56)]. (E) Immunohistochemistry analysis of $\mathrm{CD} 4^{+} \mathrm{T}\left(\mathrm{CD} 3^{+} \mathrm{CD} 8^{-}\right.$, blue) and $\mathrm{CD} 8^{+}$ $\mathrm{T}\left(\mathrm{CD} 3^{+} \mathrm{CD} 8^{+}\right.$, black) cells in urethra, fossa, and glans [representative of $n=5$ different donors for each tissue; mean age 41 years (26-54)]. Cells were stained with anti-CD3 and anti-CD8 antibodies and revealed using diaminobenzidine (brown staining) or histogreen (blue staining) peroxidase substrates. Scale bar $=50 \mu \mathrm{m}$. (F) Representative dot plot and (G) proportions of CD45RA ${ }^{+} C C R 7^{+}$naive $\left(T_{N}\right), C D 45 R A-C C R 7^{+}$central memory $\left(T_{C M}\right), C D 45 R A-C C R 7-$ effector memory $\left(T_{E M}\right)$, and CD45RA ${ }^{+} C C R 7^{-}$terminally differentiated effector $\left(T_{E}\right) C D 4^{+} T$ (upper panel) and CD8 ${ }^{+} T$ (lower panel) cells in penile tissues $[n=5$ different donors for each tissue; mean age 37 years (22-5)]. (H) Representative dot plot and (I) proportions of intermediate memory CCR7-CD27+CD4+ $T$ (left panel) and CD8 ${ }^{+} \mathrm{T}$ (right panel) cells in urethra, fossa, and glans [ $n=5$ different donors for each tissue; mean age 46 years (28-56)]. All box-and-whisker plots represent minimum-to-maximum values, and each point corresponds to one donor. Statistical analyses were performed first by the Kruskal-Wallis test; pairwise comparisons were performed by the Mann-Whitney U-test. ${ }^{*} p<0.05,{ }^{* *} p<0.01$, and ${ }^{\star * *} p<0.001$. 


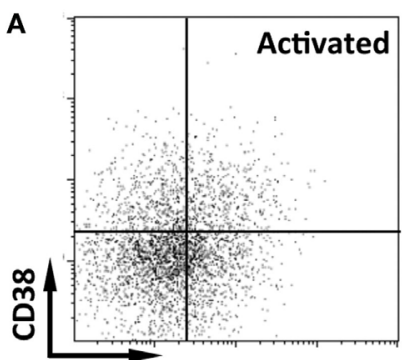

HLADR

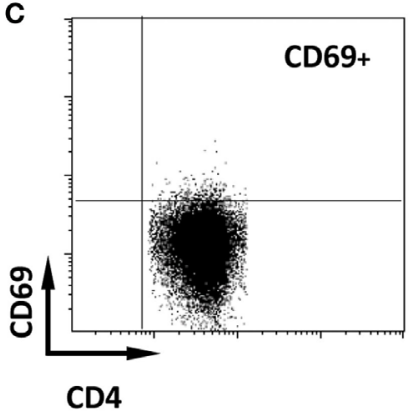

$\mathbf{E}$

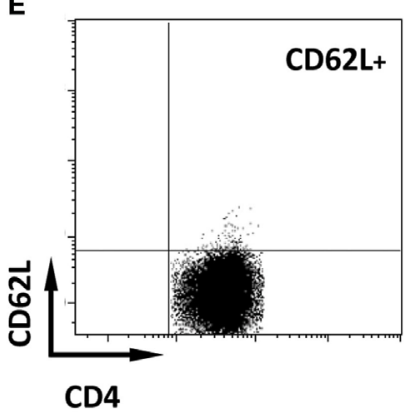

G

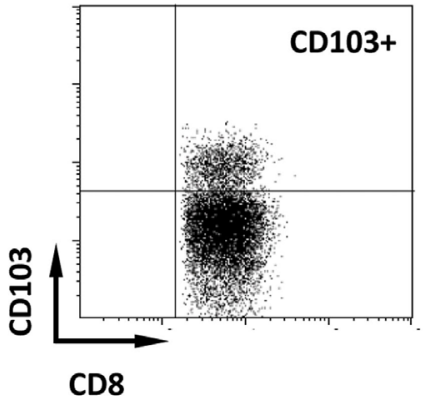

B $\mp$
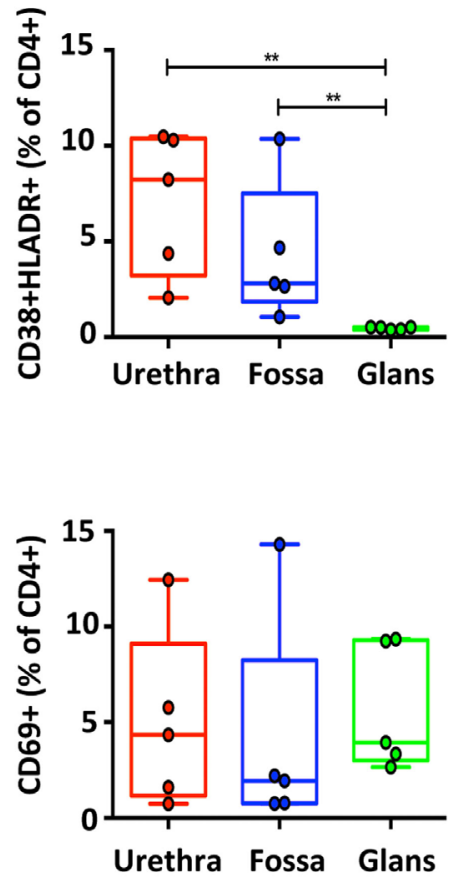

$\mathbf{F}$
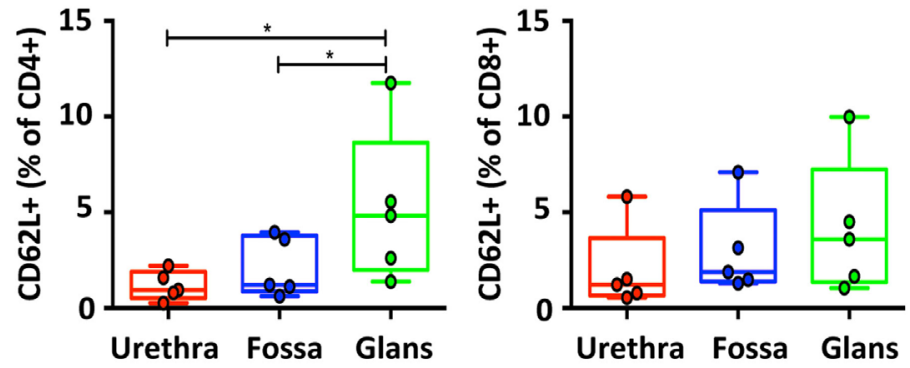

H

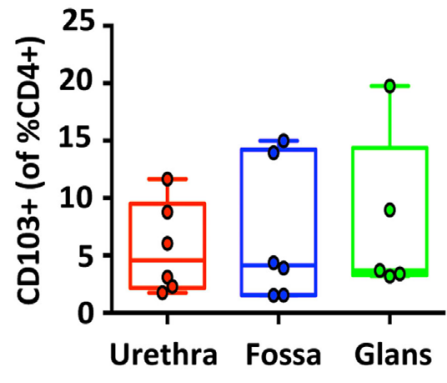

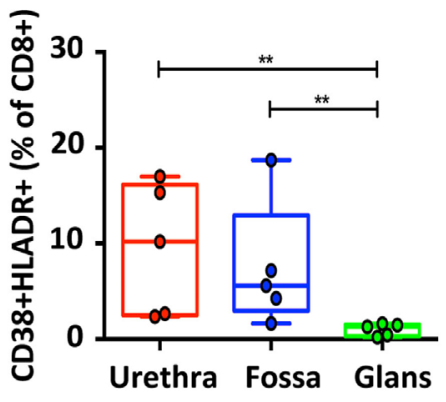

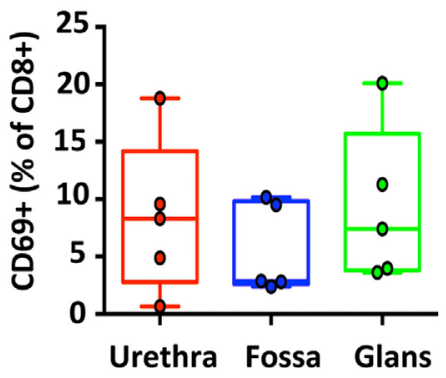

FIGURE 4 | Activation and adhesion markers of penile T cells. Representative dot plots $(\mathbf{A}, \mathbf{C})$ and box-and-whisker plots of activated $C D 45^{+} C D 3^{+} C D 4^{+}$ (referred to as $\mathrm{CD}^{+}$) [(B,D), left panel] and $\mathrm{CD} 45^{+} \mathrm{CD} 3^{+} \mathrm{CD} 8^{+}$(referred to as $\left.\mathrm{CD} 8^{+}\right) T$ cells $\left[(\mathbf{B}, \mathbf{D})\right.$, right panel]. $\mathrm{HLA}-\mathrm{DR} \mathrm{R}^{+} \mathrm{CD} 38^{+}(\mathbf{A}, \mathbf{B})$ and $\mathrm{CD} 69^{+}(\mathbf{C}, \mathbf{D})$ activated $T$ cells were detected in penile tissues by flow cytometry on $\mathrm{CD}^{+}{ }^{+}$(left panel) and CD8 ${ }^{+}$(right panel) $\mathrm{T}$ cell populations $[n=5$ different donors for each tissue; mean age 37 years (range: 22-56) for HLA-DR/CD38 staining and 46 years (28-56) for CD69 staining]. Representative dot plots and box-and-whisker plots representing expression of CD62L [(E,F), respectively, $n=5$ different donors for each tissue and mean age 46 years (28-56)] and the adhesion molecule CD103 [(G,H), respectively, $n=6,6$, and 5 different donors for urethra, fossa, and glans, respectively. Mean age 40 years (23-51)] detected by flow cytometry on CD4+ (left panel) and $\mathrm{CD}^{+}$(right panel) T cell populations. All box-and-whisker plots represent minimum-to-maximum values, and each point corresponds to one donor. Statistical analyses were performed first by the Kruskal-Wallis test; pairwise comparisons were performed by the Mann-Whitney $U$-test. ${ }^{*} p<0.05$, ${ }^{* *} p<0.01$, and ${ }^{* \star *} p<0.001$ 


\section{Cytokines Produced by Penile Cells}

$\mathrm{T}$ helper (Th) cells represent one of the most important cell type in adaptive immunity, as they are required for almost all adaptive immune responses. Once activated, Th cells secrete different types of cytokines that in turn stimulate other immune cells such as B cells, which provide help to secrete antibodies or cytotoxic $\mathrm{T}$ cells for killing infected target cells, thereby amplifying the immune response against pathogens (25). Flow cytometry was used to determine the frequency of cells producing Th1-like cytokines, namely, IFN- $\gamma$, TNF- $\alpha$, and IL- 2 , cells producing Th2-like cytokines as IL-4 and IL-5 and cells producing IL-17 and IL-22 in the different penile mucosa.

IFN- $\gamma$-secreting cells were detected in all penile tissues, with a predominance for $\mathrm{CD}^{+}$cells $(2.8 \%$ [1.6-4.1], 2.9\% [1.9-4.0], and $2.4 \%$ [2.3-2.4] in the urethra, fossa, and glans, respectively) (Figure 5C, left panel) by comparison with $\mathrm{CD}^{+}$cells $(1.7 \%$ [1.1-2.2], $0.8 \%$ [0.4-1.1], and 1.2\% [0.9-1.4] in the urethra, fossa, and glans, respectively) (Figures $5 \mathbf{A}, \mathbf{B}$, left panel). However, TNF- $\alpha$ (Figures 5B,C middle panels) and IL-2 (Figures 5B,C, right panels) secreting cells were low in these tissues (less than $1 \%$ of $\mathrm{CD}^{+}$and $\mathrm{CD}^{+}$cell populations, representative dot plots for $\mathrm{CD}^{+}$cells shown on Figure 5A).

The secretion of Th2-like cytokines by $\mathrm{CD} 4^{+}$cells was also evaluated (Figures 5D,E). CD4 ${ }^{+}$cells expressing IL-4 were detected in equivalent proportions in the urethra and the fossa (1.2\% [0.6-1.7] and 1.4\% [0.9-1.9], respectively) and slightly more abundant in the glans (3.3\% [2.2-4.3]) (Figure 5E, left panel). On the other hand, $\mathrm{CD}^{+}$cells secreting IL- 5 were in equal proportions in the urethra $(1.2 \%[1.1-1.3])$, the fossa $(1.6 \%[1.4-1.8])$, and the glans (1.7\% [1.6-1.8]) (Figure 5E, right panel).

Th17 cells correspond to a pro-inflammatory subset of $\mathrm{CD}^{+} \mathrm{T}$ cells that secrete IL-17 after stimulation. Th17 cells provide a protective inflammatory response toward pathogens in mucosal tissues, such as skin, gut, and lung. IL-17 mediates the recruitment of neutrophils and macrophages to infected tissues, thereby acting in host defense against extracellular pathogens (26). Although $\mathrm{CD}^{+} \mathrm{CD}^{+}$cells from all penile tissues secreted IL-17 (Figures 5F,G, left panel), IL-17 production in the glans appeared to be slightly higher (2.0\% [1.7-2.3]), compared with the urethra and fossa (1\% [0.6-1.3] and $0.9 \%$ [0.7-1.2], respectively). Finally, we evaluated the secretion by penile $\mathrm{CD}^{+}$cells of IL-22, a cytokine that modulates the expression of many genes encoding proteins involved in tissue protection, survival, differentiation, and remodeling, possibly exerting pro-inflammatory functions (26) (Figures 5F, G, right panel). Cells secreting IL-22 were equally frequent in the urethra $(1.2 \%[1-1.4])$, the fossa $(1.2 \%[0.9-1.5])$, and the glans $(1.2 \%[1-1.3])$.

\section{Penile NK Cells Have an Activated Profile and the Machinery to Mediate Antibody- Dependent Cell Cytotoxicity (ADCC)}

Natural killer cells, phenotypically defined as $\mathrm{CD}^{-}{ }^{-} \mathrm{CD} 56^{+}$lymphocytes, are part of the innate immune system acting as first line of defense of the organism due to their capacity of destroying infected cells without prior activation/stimulation. The intensity of CD56 expression distinguishes two subpopulations of NK cells (27), namely, the CD56 ${ }^{\text {dim }}$ cytotoxic and the CD56 $6^{\text {bright }}$ immunoregulatory NK cells.

$\mathrm{CD} 45^{+} \mathrm{CD} 3^{-} \mathrm{CD} 56^{+} \mathrm{NK}$ cells (Figure 6A) in the urethra, fossa, and glans constituted less than $3 \%$ of total $\mathrm{CD} 45^{+}$leukocytes (2.7\% [2.3-3.0]; $1 \%$ [0.8-1.3]; and $0.8 \%$ [0.1-1.5], respectively) (Figure 6B) and were mainly CD56 $6^{\mathrm{dim}}$ (Figure 6A). We can also detect $\mathrm{CD} 45^{+} \mathrm{CD}^{+} \mathrm{CD}^{+} 6^{+}$cells (Figures $\mathbf{6 A}, \mathrm{C}$ ) in these tissues, which correspond to NKT cells. This population represents $3.0 \%$ [2.2-3.7], 2.2\% [0-4.5], and 3.5\% [2.6-4.4] of total CD $45^{+}$penile cells in the urethra, fossa, and glans, respectively.

In line with this $\mathrm{CD} 56^{\text {dim }} \mathrm{NK}$ cell profile, $\mathrm{CD} 56^{+}$cells were detected at low, but specific, frequency in the lamina propria of the urethra after comparative immunochemical detection with an anti-CD56 and isotype control-matched antibody (Figure 6D, right and left panels, respectively). However, CD $56^{+}$cells appeared absent from the fossa and the glans using this technique (data not shown), most likely because CD56 expression was too low for visualization by immunohistochemistry.

The main activating receptors of penile NK cells, namely, the members of the natural cytotoxicity receptors (NCR) family NKp30, NKp44, and NKp46 (27), were expressed in different proportions in the urethra, fossa and glans (Figure 6E, upper panel). NKp44, an exclusive marker of activated cells (23), was expressed on NK cells from the urethra (29.9\% [26.5-33.3]), fossa $(23 \%$ [15.7-30.4]), and glans (45.3\% [35.2-55.5]) (Figure 6E, upper panel, middle). In addition, NK cells in all penile regions also expressed NKp30 and NKp46 (Figure 6E, upper panel, right and left) as well as the activating receptor NKG2D and the inhibiting receptor NKG2A (Figure 6E, lower panel). Finally, the Fc $\gamma$ RIII (CD16) was also highly expressed by NK cells (Figure 6E, lower panel, right) from the urethra (64.4\% [57.2-71.5]), fossa (47.7\% [35.8-59.6]), and glans (46.4\% [31.7-61.1]), suggesting that penile NK cells can bind IgGs thus acting as effector cells to mediate ADCC in pathologic conditions (Figure 6E, bottom panel).

In addition to T cells, innate immune cells including NK cells also secrete the inflammatory cytokines IL-17 and IL-22 (28). We thus evaluated whether IL-17 was spontaneously produced by penile NK cells. Only urethral NK cells secreted IL-17 (4.5\% [3.6-5.4]) unlike those from fossa and glans $(0.7 \%[0-1.5]$ and $1.6 \%[1-2.2]$, respectively) (Figure 6F, left panel). By contrast, NK cells from all penile compartments produced IL-22 $(2.9 \%$ [1.9-3.8], 1.3\% [0.5-2.2], and 2.3\% [0-6.7] in the urethra, fossa, and glans, respectively) (Figure $6 \mathrm{~F}$, right panel).

Altogether, all penile tissue regions are equally populated by $\mathrm{NKp} 44^{+}$-activated NK cells residing in the lamina propria that are equipped to trigger ADCC via the CD16 receptor, and are able to secrete spontaneously pro-inflammatory cytokines such as IL-17 and IL-22.

\section{Homing Receptors Expression by Penile Immune Cells}

We first evaluated CCR5 and CXCR4 expression on T cells (Figures 7A,B), two chemokine receptors that additionally permit $\mathrm{HIV}-1$ infection. CCR $5^{+} \mathrm{CD} 8^{+} \mathrm{T}$ cells were more numerous than 
A

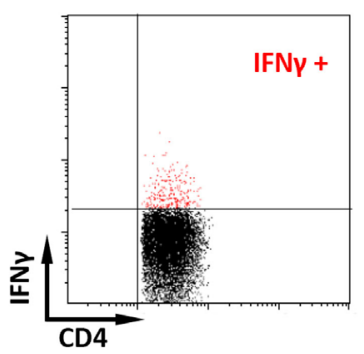

B

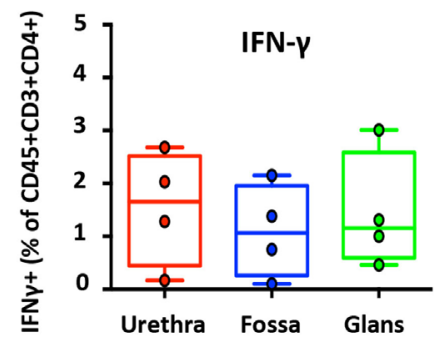

C

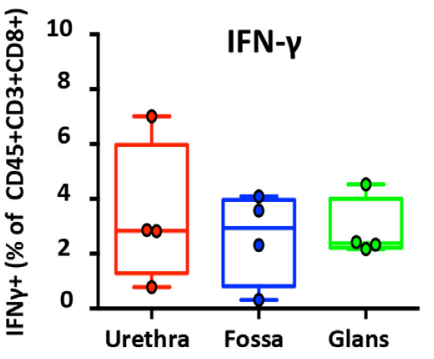

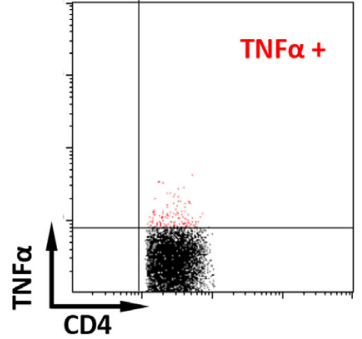
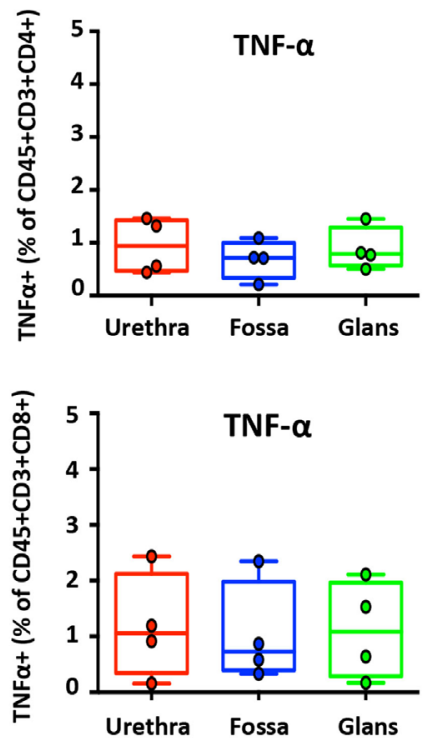

D

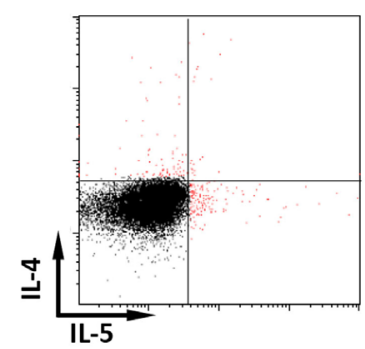

F

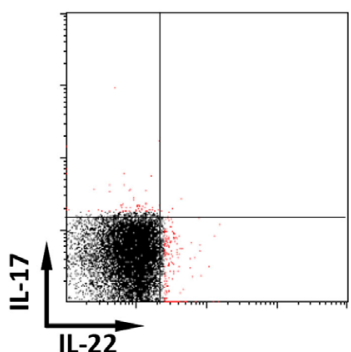

E

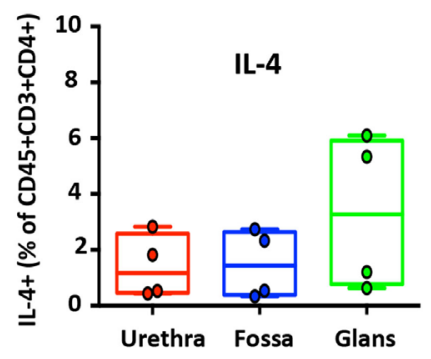

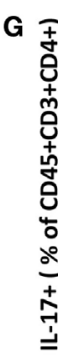

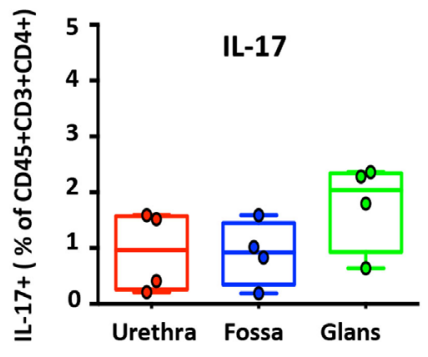

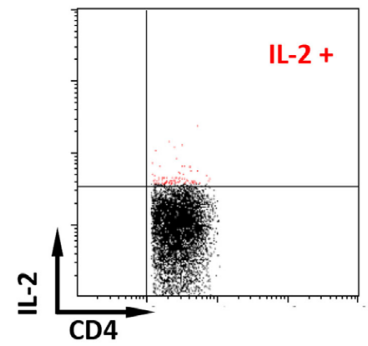
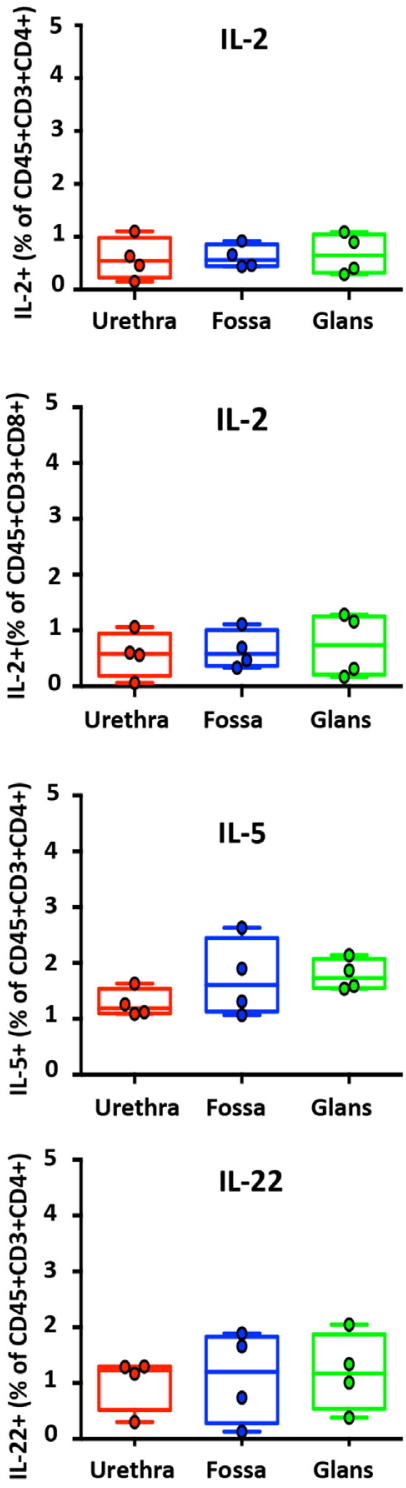

FIGURE 5 | Secretion of cytokines by penile cells. (A) Representative dot plots of spontaneous secretion of IFN- $\gamma$ (left panel), TNF- $\alpha$ (middle panel), and IL-2 (right panel) by urethral CD45 ${ }^{+} \mathrm{CD} 3^{+} \mathrm{CD} 4^{+}$. (B,C) Box-and-whisker plots representing the spontaneous secretion of IFN- $\gamma$ (left panel), TNF- $\alpha$ (middle panel), and IL-2 (right panel) by penile $\mathrm{CD}_{4} 5^{+} \mathrm{CD} 3^{+} \mathrm{CD} 4^{+} \mathbf{( B )}$ and $\mathrm{CD} 45^{+} \mathrm{CD} 3^{+} \mathrm{CD} 8^{+}$cells $\mathbf{( C )}$ after intracellular staining in the different penile tissues $[n=4$ different donors for each tissues; mean age 34 years (range: 25-51)]. Representative dot plots (D) and box-and-whisker plots (E) representing the spontaneous secretion of IL-4 [(E), left panel] and IL-5 [(E), right panel] by penile $\mathrm{CD} 45^{+} \mathrm{CD} 3^{+} \mathrm{CD} 4^{+}$cells after intracellular staining in urethra, fossa, and glans $[n=4$ different donors for each tissues; mean age 34 years (25-51)]. Representative dot plots (F) and box-and-whisker plots (G) representing the spontaneous secretion of IL-17 [(G), left panel] and IL-22 [(G), right panel] by penile $\mathrm{CD} 45^{+} \mathrm{CD} 3^{+} \mathrm{CD} 4{ }^{+}$cells after intracellular staining in the different penile tissues $[n=4$ different donors for each tissues; mean age 34 years (25-51)]. All box-and-whisker plots represent minimum-to-maximum values, and each point corresponds to one donor. 

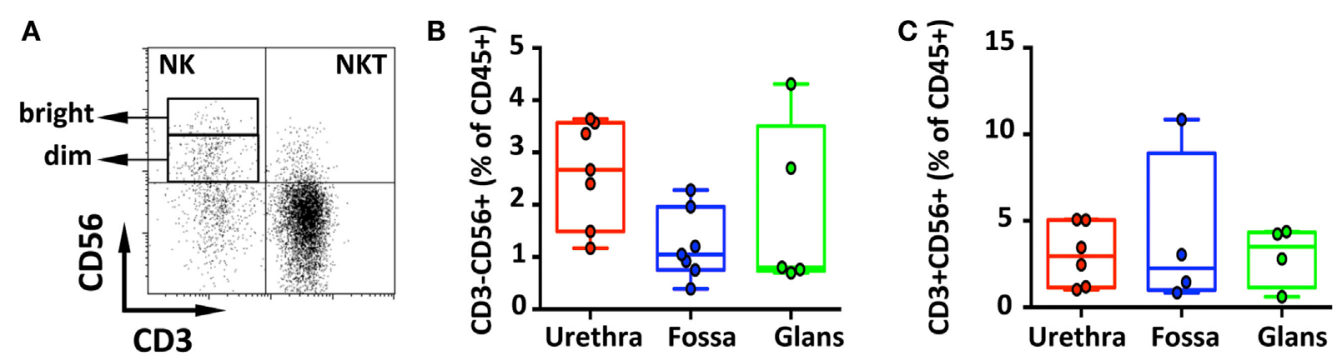

D
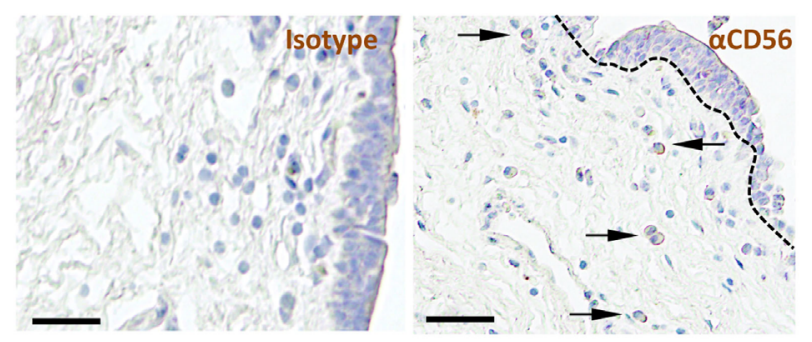

E
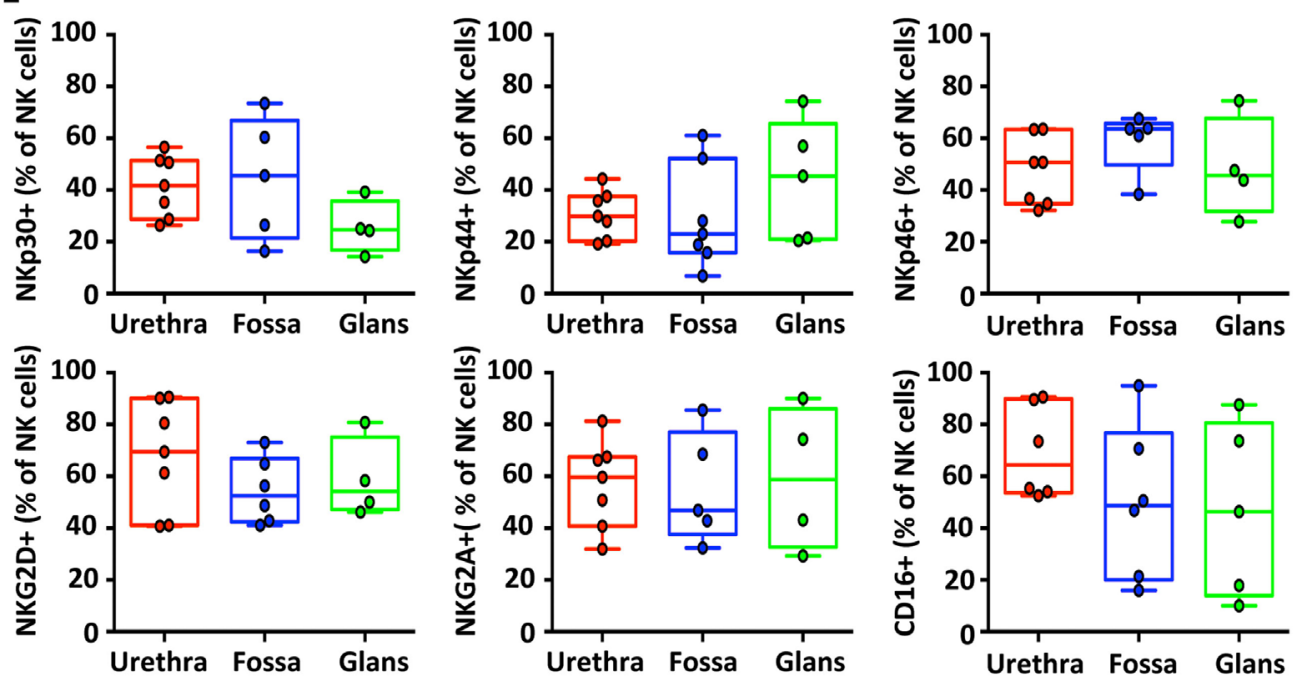

$\mathbf{F}$
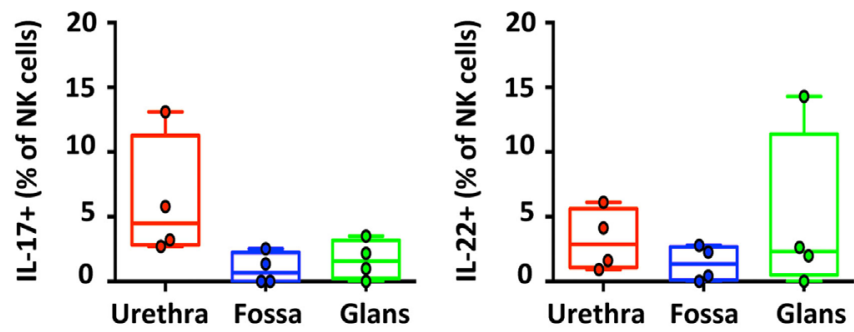

FIGURE 6 | Phenotype and distribution of penile natural killer (NK) and NKT cells. Representative dot plot (A) and box-and-whisker plots of (B) total CD45 ${ }^{+}$CD3 ${ }^{-}$CD56 ${ }^{+}$NK cells $[n=8,7$, and 5 different donors for urethra, fossa, and glans, respectively; mean age 35 years (range: 19-56)] and (C) total $\mathrm{CD}_{4}{ }^{+} \mathrm{CD}^{+}{ }^{+} \mathrm{CD} 56{ }^{+} \mathrm{NKT}$ cells detected by flow cytometry in urethra, fossa, and glans $[n=6$, 4 , and 4 different donors for urethra, fossa, and glans, respectively; mean age 35 years (19-56)]. (D) Immunohistochemistry analysis of $\mathrm{CD}^{+} 6^{+}$cells (right panel) by comparison with a mouse IgG1 isotype control (left panel) in urethral tissues [representative of $n=5$ different donors; mean age 41 years (26-54)]. Cells were stained with an anti-CD56 antibody or a mouse lgG1 isotype control and revealed using diaminobenzidine peroxidase substrate (brown staining). Scale bar $=50 \mu \mathrm{m}$. (E) Expression pattern of NKp30, NKp44, NKp46, NKG2D, NKG2A, and CD16 receptors on CD45+CD3-CD56+ NK cells in penile mucosae $[n=4-7$ different donors; mean age 35 years (19-56)]. (F) Box-and-whisker plots representing the spontaneous secretion of IL-17 (left panel) and IL-22 (right panel) by penile CD45+CD3-CD56 ${ }^{+} \mathrm{NK}$ cells after intracellular staining in urethra, fossa, and glans [ $n=4$ different donors for each tissue; mean age 34 years (25-51)]. All box-and-whisker plots represent minimum-to-maximum values, and each point corresponds to one donor. 

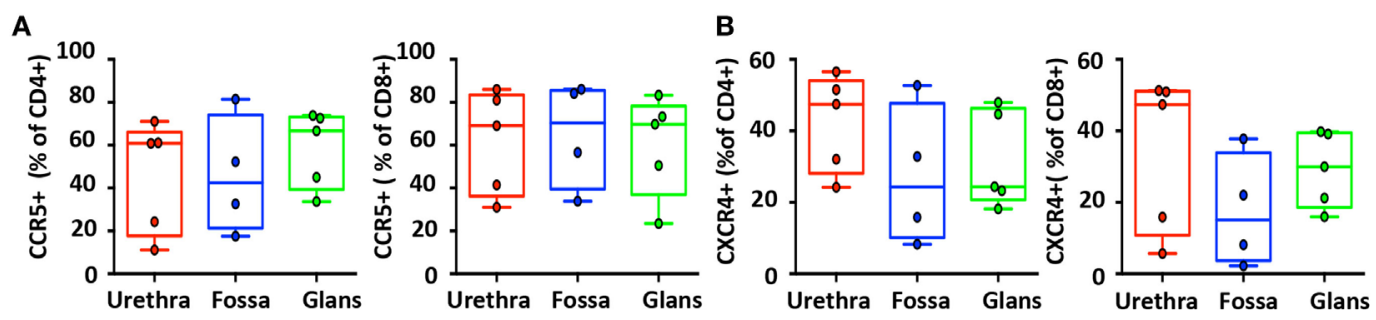

Urethra

Fossa

Glans

C
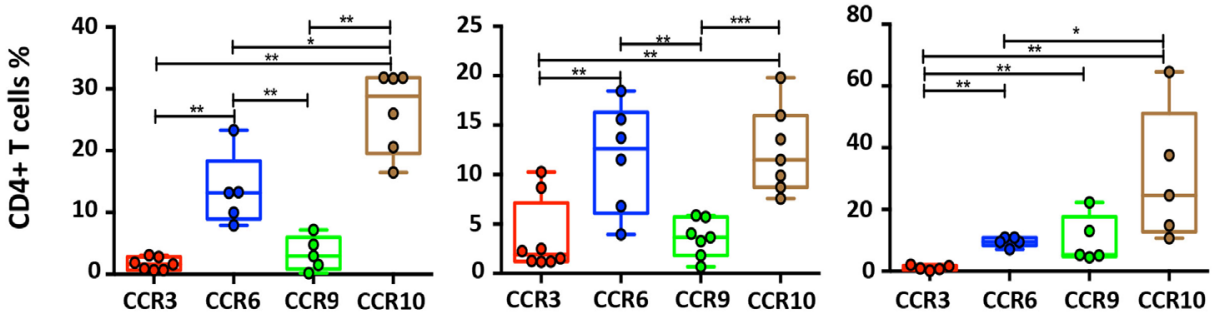

D
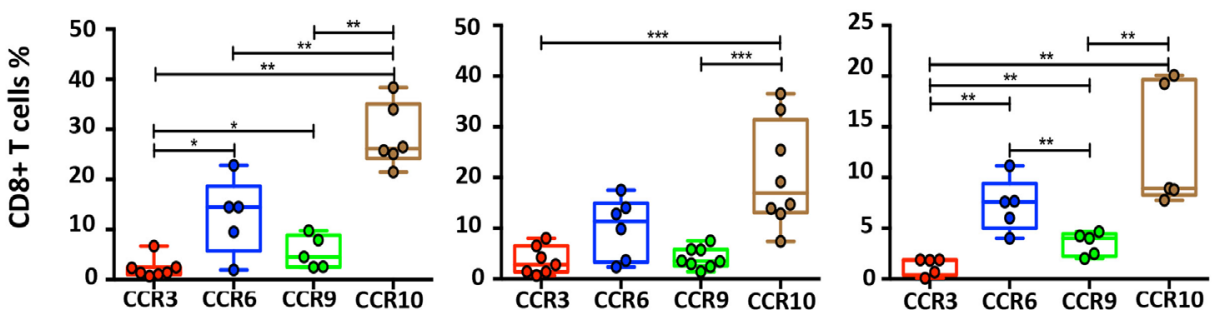

E
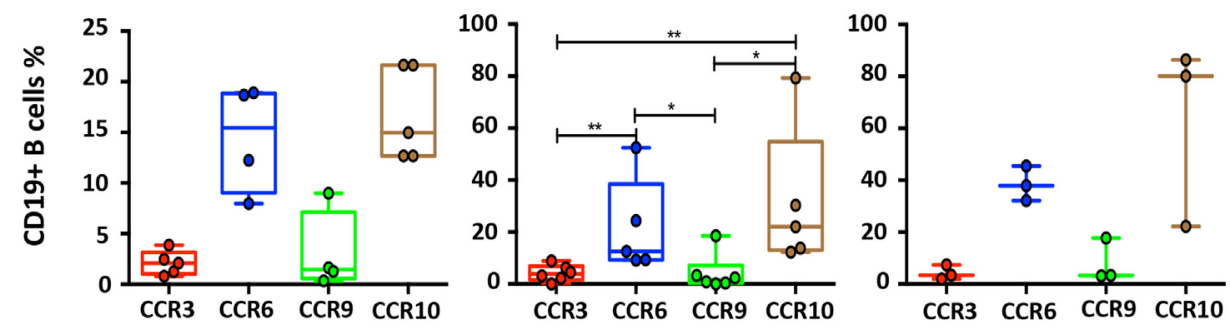

F
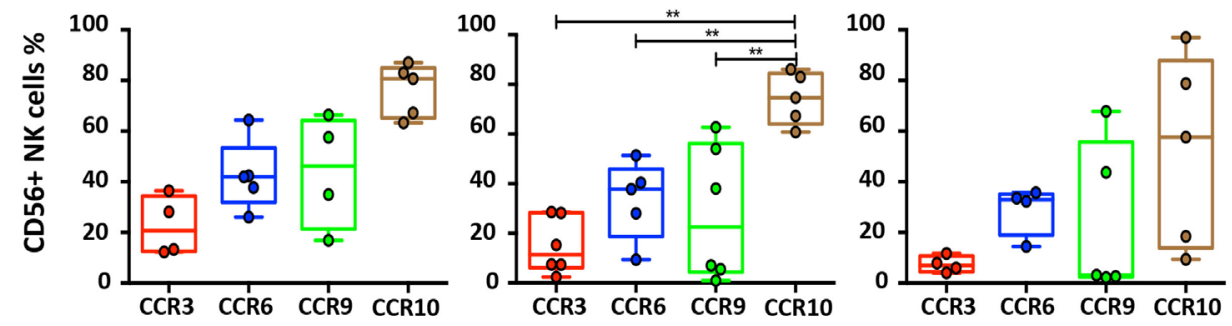

FIGURE 7 | Characterization of homing receptors profiles on the different penile cell populations. Box-and-whisker plots of $\mathrm{CD} 45^{+} \mathrm{CD} 3^{+} \mathrm{CD} 4^{+}$and $\mathrm{CD} 45^{+} \mathrm{CD} 3^{+} \mathrm{CD} 8^{+}$ T cells expressing (A) CCR5 and (B) CXCR4 receptors in urethra, fossa, and glans $[n=5$, 4, and 5 different donors, respectively; mean age 31 years (range: 22-43)]. (C-F) Box-and-whisker plots representing the expression of the CCR3, CCR6, CCR9, and CCR10 homing receptors on CD45+CD3+CD4+ ${ }^{+}$cells (C), $\mathrm{CD} 5^{+} \mathrm{CD} 3^{+} \mathrm{CD} 8^{+} \mathrm{T}$ cells (D), CD45+CD3-CD19+ B cells (E), and CD45+CD3-CD56+ natural killer (NK) cells (F) in urethra (left panel), fossa (middle panel), and glans (right panel) detected by flow cytometry [ $n=3-8$ different donors; mean age 37 years (19-58)]. All box-and-whisker plots represent minimum-to-maximum values, and each point corresponds to one donor. Statistical analyses were performed first by the Kruskal-Wallis test; pairwise comparisons were performed by the Mann-Whitney U-test. ${ }^{\star} p<0.05,{ }^{* *} p<0.01$, and ${ }^{* * *} p<0.001$.

CCR ${ }^{+} \mathrm{CD} 4^{+} \mathrm{T}$ cells in the urethra $(69.2 \%[58.5-79.8]$ vs $60.9 \%$ [49.4-72.4]), fossa (70.4\% [58.2-82.5] vs $42.5 \%$ [28.9-55.9]), and glans $(69.8 \%[59.4-80.1]$ vs $66.7 \%$ [58.8-74.6]). Furthermore, both $\mathrm{CD} 4^{+}$and $\mathrm{CD} 8^{+} \mathrm{T}$ cells expressed higher level of CXCR4 in the urethra (47.5\% [41.5-53.4] and $47.4 \%[37.8-56.9]$, respectively) compared with $\mathrm{CD} 4^{+}$and $\mathrm{CD} 8^{+} \mathrm{T}$ cells from fossa $(24.3 \%$ 
[13.2-35.5] and 15.1\% [7.3-22.8], respectively) and glans (24.4\% [18.4-30.3] and 30\% [25.3-34.6], respectively).

Next, we assessed the surface expression of homing receptors, namely, CCR3, CCR6, CCR9, and CCR10. CCR6 and CCR10 were expressed at a significantly higher level than CCR3 and CCR9 on B, $\mathrm{CD}^{+}$, and $\mathrm{CD}^{+} \mathrm{T}$ cells in all penile regions (Figures $7 \mathrm{C}-\mathrm{E}$ ). Furthermore, expression of CCR6 and CCR10 on NK cells (Figure 7F) in the different penile regions was higher compared with $\mathrm{B}, \mathrm{CD}^{+}$, and $\mathrm{CD}^{+} \mathrm{T}$ cells. Finally, whereas less than $5 \%$ of $\mathrm{B}$ and $\mathrm{T}$ cells expressed CCR3 and CCR9 in all penile regions (Figures 7C-E), NK cells expressed higher levels of both CCR3 in the urethra, and CCR9 in all penile compartments (Figure 7F).

Thus, CCR10 and CCR6, and to a lesser extend CCR3 and CCR9, might participate in the differential homing of these mucosal immune cells into penile tissues.

\section{Urethra, Fossa, and Glans Have Different Cytokine Environments}

Cell homing is driven by chemokine receptor expression, and their capacity to bind to the appropriate chemokines/cytokines expressed specifically in each target mucosal tissue. We therefore evaluated which chemokines/cytokines were constitutively expressed in the various penile mucosal regions. Tissue pieces derived from the three penile regions were lysed, and the supernatants were analyzed for the presence of MCP-1/CCL2, MCP-4/ CCL13, Eotaxin/CCL11 (ligands of CCR3), MIP-3 $\alpha /$ CCL20 (one ligand of CCR6), CCL25 (the ligand of CCR9), CTACK/ CCL27 and CCL28 (the ligands of CCR10), RANTES/CCL5 (one ligand of CCR5), TRAIL/TNFS10 (a member of the tumor necrosis factor family of ligands capable of initiating apoptosis through engagement of cell death receptors), and the inflammatory cytokines IL-4 and IL-13 using the luminex and quantikine technologies (Figure 8).

In the urethra (Figure 8, blue line) CCL27, MCP-4, Eotaxin, MIP-3 $\alpha$, and IL- 4 were detected at low concentrations $(0.2-1.9 \mathrm{pg} / \mathrm{ml} \mathrm{mg}$ of tissue, $n=6$ different tissues), whereas RANTES, IL-13, and CCL28 concentrations were 100 times higher (108.0-1,436.5 pg/ml mg of tissue, $n=6$ different tissues). MCP-1, TRAIL, and CCL25 concentrations were intermediate (14.0-44.1 pg/ml mg). In fossa and glans (Figure 8, red and green lines, respectively), MIP-3 $\alpha$, IL-4, IL-13, TRAIL, and CCL25 were detected at concentrations equivalent to those measured in the urethra. However, CCL28 and RANTES concentrations were 10 and 100 times lower than that in the urethra, respectively. Finally, MCP-1 was detected in the glans and urethra but not in the fossa.

Altogether, the tissue cytokine milieu varies with the penile tissue regions, with the urethra appearing to be the richest one.

\section{DISCUSSION}

Numerous pathogens including viruses and bacteria use the human penis as a portal of entry into the body and a vaccine locally active against such pathogens is key to control the spread

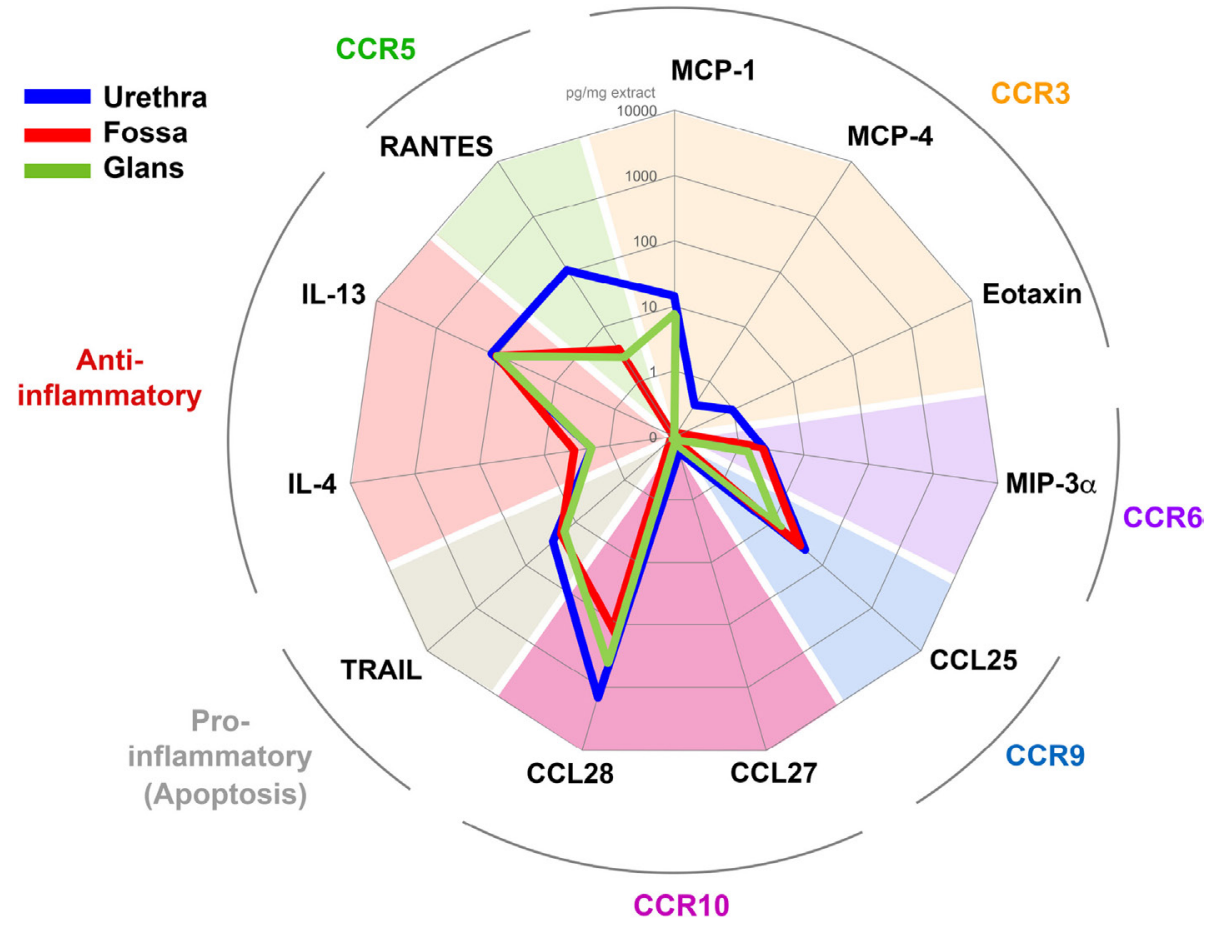

FIGURE 8 | Penile tissues have different cytokine environments. Radar representation of the different mean concentrations of cytokines/chemokines detected in urethra (blue line, $n=6$ ), fossa (red line, $n=3$ ), and glans (green line, $n=3$ ). Each concentration is expressed in picogram per milligrams of protein tissue extract and is represented on a logarithmic scale. Each cytokine/chemokine is grouped according to its specificity for their respective homing receptor or their immunological function as indicated in colored characters outside the circle. 
of STIs. Establishment of immune memory against pathogens occurs naturally after infection and permits to establish a faster specific immune response following a second contact with the pathogen.

Unlike that of the other penile regions, the mucosal immune system of the foreskin has been intensively studied and characterized. Thus, the lamina propria and the epithelium of the human foreskin selectively contain macrophages

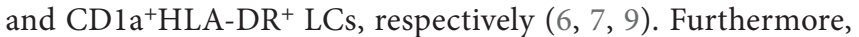
the foreskin also harbors dendritic cells and numerous EM T cells, including $\mathrm{CD}^{+}$Th17 cells (29). Finally, the foreskin epithelium is also protect by Mucin proteins, such as MUC1 and MUC4, and expresses TLRs, particularly TLR5 (16), TLR4 and TLR3 (30), thus endowing this tissue with an important anti-infectious potential.

An effective vaccine must ideally induce such pathogenspecific immune memory by inducing local specific humoral and cellular responses, in turn preventing mucosal pathogen entry and establishment of infection. Therefore, the first requirement for elaborating a protective vaccine in the penis is to evaluate whether the penile tissue possesses the appropriate set of mucosal immune cells able to target each penile compartment, and to develop a protective local immune response.

Mucosal B cells, and particularly the most abundant memory $B$ cells we found in all penile regions, are fundamental for the development of a long-lived vaccine humoral response. Longlived humoral memory comprises two major components, namely, memory B cells that search for their specific antigen in the periphery allowing for later affinity maturation, proliferation, and differentiation (31), and the PCs that locally produce specific immunoglobulins.

Penile memory B cells comprise CD $21^{-} \mathrm{CD} 27^{-} \mathrm{FCRL} 4^{+} \mathrm{B}_{\mathrm{TLM}}$, most abundant in all penile regions and reaching even $75 \%$ of glans $\mathrm{B}$ cells. $\mathrm{B}_{\mathrm{TLM}}$ that lack the memory marker CD27 are an exhausted B cells subset (32), which also express numerous inhibitory receptors containing immunoreceptor tyrosine-based inhibitory motifs as well as FcRL4 (32). The high expression of FcRL4 on urethral B cells we report may control BCR-dependent proliferation $(19,31,33)$. Hence in the context of HIV-1 infection, FCRL4 in $\mathrm{B}_{\mathrm{TLM}}$ cells negatively controls the production of cytokines by $\mathrm{B}_{\mathrm{TLM}}$ cells, but also limits the secretion rate of HIV-1 specific antibodies.

Penile memory $\mathrm{B}$ cells include also the $\mathrm{CD} 21^{-} \mathrm{CD} 27^{+} \mathrm{B}_{\mathrm{AM}}$ that are long-lived, express the BCR, and have already undergone the processes of class switching and antibody affinity maturation. Upon pathogen infection, these $\mathrm{B}_{\mathrm{AM}}$ transform into $\mathrm{CD} 27^{+} \mathrm{CD} 38^{+} \mathrm{CD} 138^{+}$PCs that will produce large amounts of antibodies, particularly IgG or IgA. $\mathrm{B}_{\mathrm{AM}}$ represent $30 \%$ of total B lymphocytes in the urethra and fossa but only $15 \%$ in the glans. $\mathrm{CD} 38^{+} \mathrm{CD} 138^{+}$PCs were found in all penile compartments although in limited quantity, residing in the tissue lamina propria. Although we did not determine the immunoglobulin isotype secreted by penile PCs, these cells in the urethra and fossa are known to predominantly secrete polymeric IgA and $\operatorname{IgM}$ that translocate through urethral epithelium in a polymeric immunoglobulin receptor-dependent manner, thus releasing secretory SIgA or SIgM in the urethral canal $(5,6)$. In addition, mucosal PCs secreting IgG locally are also present in various mucosa (34) including the foreskin (35) where IgGs translocate across the epithelium in a FcRn-dependent manner (36). Thus $\mathrm{B}_{\mathrm{AM}}$ cells and in turn PCs will most likely respond locally to a mucosal vaccine, allowing a rapid and specific response against the targeted pathogen.

How B cells home specifically into the various penile compartments remains unclear. Among the chemokine receptors expressed on penile B cells in the urethra, fossa, and glans, we now show that CCR6 and CCR10 likely drive penile homing, although CCR6 usually mediates mucosal homing to inflamed tissues including lung and gut (37). Especially in the urethra, CCR6 might promote homing as CCR6 chemotaxes toward CCL20/ MIP-3 $\alpha$, a chemokine we found enriched in the urethral compartment. Furthermore CCL28, one ligand of CCR10 detected in all penile tissues, might also participate in penile homing of B cells, as in the female genital tract (38).

In our study, $\mathrm{CD}^{+} \mathrm{T}$ cells represent the major immune cell population of all the penile regions. Although $\mathrm{CD}^{+} \mathrm{T}$ cellmediated immunity is crucial in antiviral defense, $\mathrm{CD}^{+}{ }^{+} \mathrm{T}$ cells remain the determinant $\mathrm{T}$ cell subpopulation mediating a wide variety of actions on other immune actor cells, either directly by cell-cell contact or indirectly via chemokine/cytokine secretion. Hence, $\mathrm{CD}^{+} \mathrm{T}$ cells represent half of all $\mathrm{T}$ cells in all penile regions, thus contrasting with the female genital tract (39). Of note, using morphological studies, other reported that $\mathrm{CD}^{+}$predominate over $\mathrm{CD} 4^{+} \mathrm{T}$ cells in the male genital tract (6), although this apparent contradiction most likely resides in the differences in techniques used, namely, immunohistochemistry (6) vs the more quantitative flow cytometry approach we used here.

Similar to other genital tissues, such as the foreskin (29), cervix and endometrium (40), and other mucosa (41), we show here that resting EM cells are the dominant $\mathrm{T}$ cell subset in all penile compartments. Within the $\mathrm{CD}^{+} \mathrm{T}$ population, EM cells are long-lived cells derived from effector cells, which migrate into infected tissues to eliminate. Upon reinfection, $\mathrm{CD}^{+} \mathrm{T}_{\mathrm{EM}}$ secrete different effector cytokines and chemokines resulting in a faster and more efficient secondary response.

All penile tissues contained cells able to secrete pro- and antiinflammatory cytokines that regulate the immune response and the recruitment of immune cells to sites of pathogen infection (25). Their proportions in the different penile mucosa correspond to that described in the foreskin (29) or the sigmoid colon $(42,43)$, but differ from that of the female genital tract mucosa such as the endometrium (44). As penile T cells are resting cells, one might suggest that upon activation, as can occur during infection, for example, by HIV, these T cell subsets are induced to secrete their characteristic cytokines.

Of note, the amount of effector $\mathrm{T}$ cells among the $\mathrm{CD} 8^{+} \mathrm{T}$ cell population is higher than that of $\mathrm{CD} 4^{+} \mathrm{T}$ cell population, especially in the glans. Unlike their $\mathrm{CD} 4^{+}$counterparts, $\mathrm{CD} 8^{+}$effector cells correspond to a terminally differentiated cell population and are derived from $\mathrm{T}_{\mathrm{EM}}(45)$. Thus, the increased presence of these effector cells in the lamina propria of the different penile tissues reflects an intense immune response, but also a continuous immunological monitoring at these sites. 

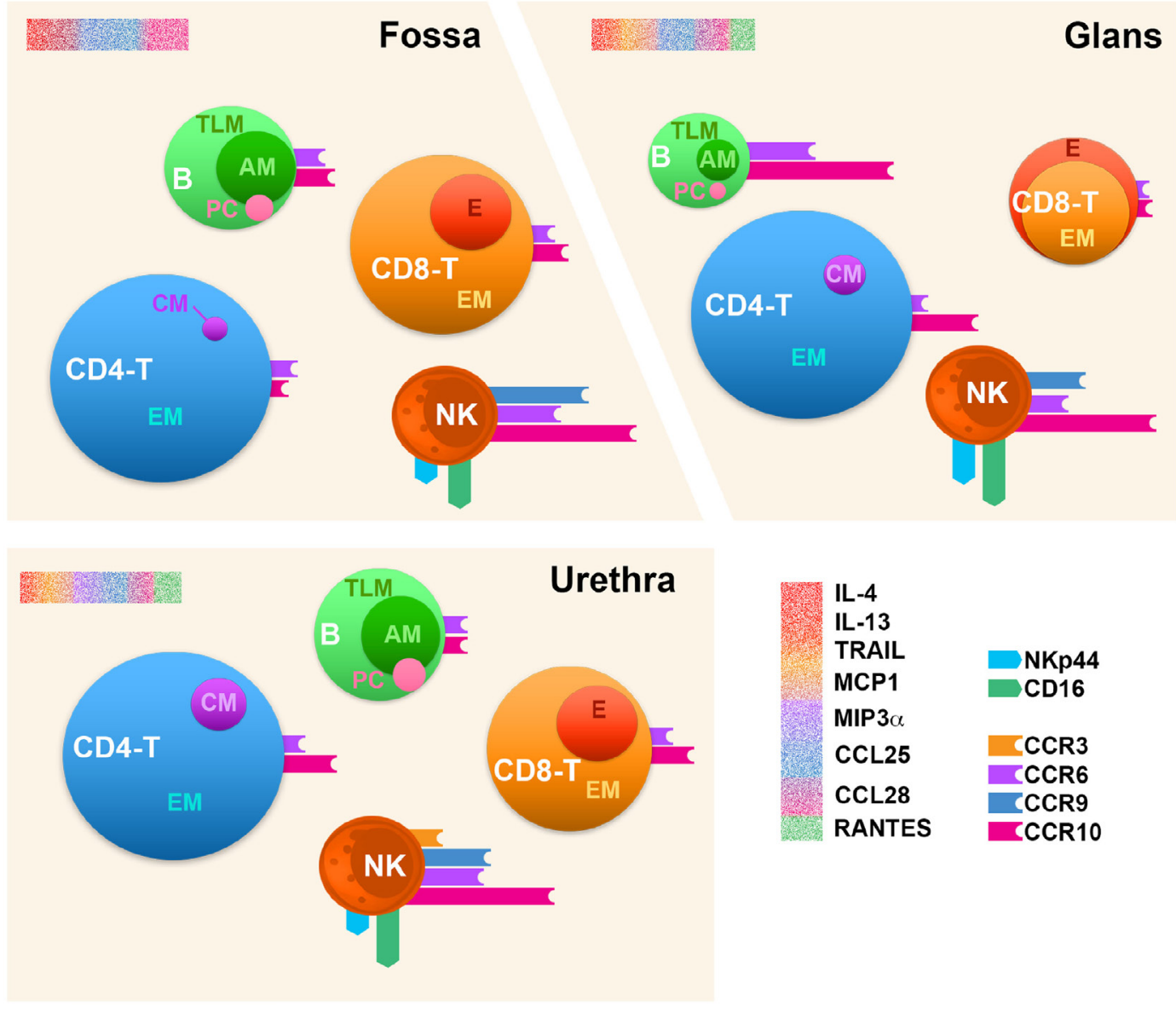

FIGURE 9 | Immune cell distribution in the human penile tissue compartments. Penile CD4+/CD8 ${ }^{+} \mathrm{T}$ cells $\left(\mathrm{CD} 4^{-} \mathrm{T}\right.$ and $\left.\mathrm{CD} 8^{-} \mathrm{T}\right)$, B cells (B), and natural killer (NK) cells' profiles in the three penile compartments, namely, urethra, fossa, and glans tissues based on the comparison of median values per each analysis. The size of each sphere corresponds to the percentage of cells relative to CD45+ leukocytes. CM, central memory; EM, effector memory; E, effector; TLM, tissue-like memory; AM, activated memory; PC, plasma cell. The expression of homing receptors (CCR3, CCR9, CCR6, and CCR10), the chemokine receptor CCR5, and NK activation receptors (NKp44 and CD16) is represented by colored bars attached to spheres; bar size corresponds to the percentage of cells expressing the receptors among each cell type. Profiling of cytokines for each penile tissue was also performed and is represented by a sprinkled bars colored according to their cognate receptor or functions in red (IL-4, IL-13, and TRAIL), orange (MCP-1), purple (MIP-3 $\alpha$ ), blue (CCL25), magenta (CCL28), and green (RANTES) (upper-left corner of each scheme region).

Penile $\mathrm{CD}^{+} \mathrm{T}$ cells are essentially memory cells that express the mucosal $\alpha E / \beta 7$ integrin (CD103) which could explain their epithelial localization throughout the penile regions. Accordingly, this homing receptor retains $\mathrm{T}$ cells in genital epithelia but also in other mucosa, such as the gut, by interacting with E-cadherin expressed by epithelial cells (46). Such CD103+ $\mathrm{T}$ cells are most likely the non-recirculating resident memory $\mathrm{T}$ cell subset known to remain in tissues and prone to initiate a rapid immune response after resensitization (24).

Conversely, the recirculating $\mathrm{T}$ cell subset looses expression of CD103 and also the early activation marker CD69, thus cells devoid of these two markers might represent penile $\mathrm{CD} 4^{+}$ $\mathrm{T}$ cells. Indeed, $\mathrm{CD}^{+} \mathrm{CD} 4^{+} \mathrm{CD} 103^{-} \mathrm{CD} 69^{-}$cells are present in all penile regions studied here, similar to most non-lymphoid tissues (40). This particular CD 103- ${ }^{-}$D69- double negative phenotype associated with the expression of the HIV-1 co-receptor CCR5 on penile $\mathrm{CD} 4^{+} \mathrm{T}$ cells might explain the dissemination of
HIV-1 in the host following penile infection of resident urethral macrophages (10), and potential subsequent transfer to $\mathrm{CD}^{+}$ $\mathrm{T}$ cells. Although CD103 participates in the mucosal homing and residence of $\mathrm{T}$ cells in the female genital tract (46), the role of other receptors implicated in $\mathrm{T}$ cells homing into male or female genital tissues remains elusive, although $\mathrm{T}$ cells homing in other mucosa is better documented. For example, CCR9 and the $\alpha 4 \beta 7$ integrin participate in homing to the gut (47), whereas CCR3 and CCR10 are involved in T cell-mediated skin inflammation (48) and in CD4 ${ }^{+} \mathrm{T}$-cell infiltration in the nasal mucosa (49). We suggest here that in addition to CCR10 and CCR6, CCR 5 that is also expressed by penile $\mathrm{T}$ cells might participate in penile tissue homing due to the high concentration, especially in the urethra and fossa, of penile RANTES/CCL5, the natural ligand of CCR5.

Innate immune cells are also present in penile tissues including macrophages, as we have shown earlier (10), and NK cells 
as we reported here, similar to other genital tissues. Hence, vaginal NK cells are among the first ones recruited to sites of new infections, along with other innate and adaptive immune cells (50). Furthermore, vaginal NK cells participate in the control of pathogens such as HSV, as patients with defective NK cells show an increased susceptibility to HSV infections (50). Throughout the penis, NK cells are essentially CD56 ${ }^{\mathrm{dim}}$ and harbor the Fc- $\gamma$ Receptor CD16, associated with the "cytotoxic" NK cell subset described in the blood. Such CD56 ${ }^{\mathrm{dim}}$ NK cells proliferate little and produce low level of cytokines, at least in vitro (27). Accordingly, CD16 is the principal Fc- $\gamma$ receptor of glans NK cells (51). Furthermore, penile NK cells strongly express all the members of the NCR family (27), namely, NKp30, NKp44, and NKp46 as we show herein. NKp30 and NKp46 are constitutively expressed on all NK cells of healthy individuals, whereas NKp44 is expressed only after activation $(23,27)$. Penile NK cells are phenotypically similar to lung NK cells that are also CD $56^{\text {dim }} \mathrm{CD} 16^{+}$and mostly NKp46 ${ }^{+}$(52), thus corresponding to blood NK cells. By contrast, penile NK cells differ from CD56 $6_{\text {bright }} \mathrm{CD16} 6_{+-}$NK cells gut (53) and female reproductive tract (FRT) (54) that are comparable to immature NK cells found in secondary lymphoid tissues and known to produce higher amounts of inflammatory cytokines and harbor low cytotoxicity potential.

$\mathrm{NKp} 44^{+}$and $\mathrm{NKp} 46^{+}$expression indicates that penile $\mathrm{NK}$ contains the two subsets of NK cells identified at the mucosal level, namely, the NKp44+ NK cells able to secrete IL-17 and IL-22, and the NKp $46^{+}$NK cells producing IFN- $\gamma(28,55)$. IL-17 is a pro-inflammatory cytokine allowing for the accumulation of immune cells on the mucous surface, but also for the secretion of antimicrobial peptides by epithelial cells (26), whereas IL-22 confers protection to mucosal surfaces against bacterial and fungal infection, and promotes inflammation and the recruitment of immune cells at these sites (43). In addition, one of the other roles of IL-22 is to stimulate the secretion of the anti-inflammatory cytokine IL-10, by the epithelial cell barrier, allowing the preservation of its integrity (56). The secretion of these cytokines depends on IL-23 that is mainly produced by DCs, macrophages, and NK cells themselves following stimulation by lipopolysaccharides and the activation of the TLR 4 as part of the innate immunity.

Thereby, in addition to their immune surveillance and putative cytotoxic functions, penile NK cells are therefore involved in the inflammatory reactions, thus allowing the establishment of the immune response orchestrated by $\mathrm{B}$ and $\mathrm{T}$ cells previously described.

Overall, as schematized in Figure 9, we show here that the human penis resembles other mucosal immunological tissues. Concerning $\mathrm{T}$ cell subsets, their relative proportions ressemble that of the foreskin (29) and ectocervix (57) but also non-genital tissues (41). B cells relative proportion is also similar to that of other immunologically active mucosa such as the FRT (57), but clearly different from that of the GIT (58) where B cells represent one quarter of the total immune cells. Furthermore, if penile NK cells are phenotypically similar to those found in the lungs, they approximate in proportion to those found in the cervix but are much less abundant than in the endometrium (57). Finally, taken the cytokine/chemokine environment together with chemokine receptors we studied here, CCR10 the best expressed one together with CCR6, CCR3, and CCR9 might participate in the homing of penile immune cells. Differential chemokine receptor expression in each penile compartment suggests that each specific combination of these receptors contributes to specific homing to each penile region. Of note, the frequency of CCR6 and CCR10 expression is always greater than that of the two other receptors, in particular for NK cells.

In conclusion, the human male urethra and the fossa exhibit an immunological composition close to those of other mucosal effector sites, as the foreskin (29) or the FRT (57). Strikingly, the glans shows effector features superior to that of the urethra and the fossa, due to the presence of more activated NK cells and the presence of more terminally differentiate effector $\mathrm{CD} 8^{+} \mathrm{T}$ cells. Thus, one might suggest that the glans is a site more sensitive to an infection such as HIV, whereas the two other more inner penile compartments, namely, fossa and urethra, allow for protection due of their specific immune composition. Nevertheless, urethra, fossa, and glans contain all the components necessary to host an innate immune response with the presence of activated NK cells, as well as an effector adaptive immune response due to the presence of PCs, memory B, and EM T cells. However, our results suggest that the induction of $\mathrm{B}$ and $\mathrm{T}$ cell responses most likely does not occur in these tissues but rather in draining lymph node, since lymphoid follicles are absent in the penis (6).

Altogether from the present study, the human penis emerges as an efficient mucosal effector site, which contains cell subsets required to induce and generate specific and effective immune responses against mucosal pathogens. This study provides an invaluable source of information on the penile immune system that might contribute to elaborating vaccine strategies against STIs targeting the male genital tract, such as HIV-1.

\section{ETHICS STATEMENT}

The study was performed according to local ethical regulations, following approval by the local ethical committee [Comité de Protection des Personnes (CPP) Île-de-France XI, approval no. 11016]. All subjects gave written informed consent in accordance with the Declaration of Helsinki.

\section{AUTHOR CONTRIBUTIONS}

AS, FR, YG, and MB conceived and designed the experiments; $\mathrm{AS}, \mathrm{FR}, \mathrm{MD}, \mathrm{SH}$, and DD performed the experiments; AS, FR, and $\mathrm{MB}$ analyzed data and wrote the article; MR and SC enrolled patients and peformed the surgery.

\section{ACKNOWLEDGMENTS}

The authors thank the patients for their participation in the study. This study was supported by grants to MB and fellowships to AS from Société d'Accélération de Transfert de Technologies (SAAT) Ile-de-France INNOV, the French National Agency for AIDS and Hepatitis research (Agence Nationale de Recherche sur le SIDA et les Hépatites, ANRS), and by fellowship to FR from SIDACTION. The authors would like to acknowledge Karine Bailly, Emmanuelle 
Maillard, and Muriel Andrieu of the CYBIO platform (Cochin Institute) and Martine Roussel (Cochin Hospital, AP-HP) for their help and advice as well as Jean-Philippe Wolf (Reproductive Biology Service, Cochin Hospital AP-HP) for fruitfull discussions at the start of the study.

\section{REFERENCES}

1. Yarbrough ML, Burnham C-AD. The ABCs of STIs: an update on sexually transmitted infections. Clin Chem (2016) 62(6):811-23. doi:10.1373/ clinchem.2015.240234

2. Shigehara K, Sasagawa T, Kawaguchi S, Kobori Y, Nakashima T, Shimamura M, et al. Prevalence of human papillomavirus infection in the urinary tract of men with urethritis: human papillomavirus in men. Int J Urol (2010) 17(6):563-8. doi:10.1111/j.1442-2042.2010.02521.x

3. Al-Mously N, Eley A. Interaction of Chlamydia trachomatis serovar E with male genital tract epithelium results in secretion of proinflammatory cytokines. J Med Microbiol (2007) 56(8):1025-32. doi:10.1099/jmm.0.47241-0

4. Edwards JL, Apicella MA. The molecular mechanisms used by Neisseria gonorrhoeae to initiate infection differ between men and women. Clin Microbiol Rev (2004) 17(4):965-81. doi:10.1128/CMR.17.4.965-981.2004

5. Pudney J, Anderson DJ. Immunobiology of the human penile urethra. Am J Pathol (1995) 147(1):155.

6. Anderson D, Politch JA, Pudney J. HIV Infection and immune defense of the penis: HIV infection of the penis. Am J Reprod Immunol (2011) 65(3):220-9. doi:10.1111/j.1600-0897.2010.00941.x

7. Ganor Y, Zhou Z, Tudor D, Schmitt A, Vacher-Lavenu M-C, Gibault L, et al. Within $1 \mathrm{~h}, \mathrm{HIV}-1$ uses viral synapses to enter efficiently the inner, but not outer, foreskin mucosa and engages Langerhans-T cell conjugates. Mucosal Immunol (2010) 3(5):506-22. doi:10.1038/mi.2010.32

8. Ganor Y, Bomsel M. HIV-1 transmission in the male genital tract: HIV-1 entry at the foreskin. Am J Reprod Immunol (2011) 65(3):284-91. doi:10.1111/j.1600-0897.2010.00933.x

9. Zhou Z, Barry de Longchamps N, Schmitt A, Zerbib M, Vacher-Lavenu M-C, Bomsel M, et al. HIV-1 efficient entry in inner foreskin is mediated by elevated CCL5/RANTES that recruits $\mathrm{T}$ cells and fuels conjugate formation with Langerhans cells. PLoS Pathog (2011) 7(6):e1002100. doi:10.1371/journal. ppat. 1002100

10. Ganor Y, Zhou Z, Bodo J, Tudor D, Leibowitch J, Mathez D, et al. The adult penile urethra is a novel entry site for HIV-1 that preferentially targets resident urethral macrophages. Mucosal Immunol (2013) 6(4):776-86. doi:10.1038/mi.2012.116

11. Lehner T, Tao L, Panagiotidi C, Klavinskis LS, Brookes R, Hussain L, et al. Mucosal model of genital immunization in male rhesus macaques with a recombinant simian immunodeficiency virus p27 antigen. J Virol (1994) 68(3):1624-32.

12. Caputo SL, Trabattoni D, Vichi F, Piconi S, Lopalco L, Villa ML, et al. Mucosal and systemic HIV-1-specific immunity in HIV-1-exposed but uninfected heterosexual men. AIDS (2003) 17(4):531-9. doi:10.1097/00002030200303070-00008

13. Husband AJ, Clifton VL. Role of intestinal immunization in urinary tract defence. Immunol Cell Biol (1989) 67(Pt 6):371-6. doi:10.1038/icb.1989.53

14. Hickey DK, Patel MV, Fahey JV, Wira CR. Innate and adaptive immunity at mucosal surfaces of the female reproductive tract: stratification and integration of immune protection against the transmission of sexually transmitted infections. J Reprod Immunol (2011) 88(2):185-94. doi:10.1016/j. jri.2011.01.005

15. Cole AM, Cole AL. Review article: antimicrobial polypeptides are key anti-HIV-1 effector molecules of cervicovaginal host defense: antimicrobial polypeptides in vaginal defense. Am J Reprod Immunol (2007) 59(1):27-34. doi:10.1111/j.1600-0897.2007.00561.x

16. Pudney J, Anderson DJ. Expression of toll-like receptors in genital tract tissues from normal and HIV-infected men: toll-like receptors in human male genital tissues. Am J Reprod Immunol (2011) 65(1):28-43. doi:10.1111/j. 1600-0897.2010.00877.x

\section{SUPPLEMENTARY MATERIAL}

The Supplementary Material for this article can be found online at http://www.frontiersin.org/articles/10.3389/fimmu.2017.01732/ full\#supplementary-material.

17. Prodger JL, Gray R, Kigozi G, Nalugoda F, Galiwango R, Nehemiah K, et al. Impact of asymptomatic herpes simplex virus- 2 infection on $\mathrm{T}$ cell phenotype and function in the foreskin. AIDS (2012) 26(10):1319-22. doi:10.1097/ QAD.0b013e328354675c

18. McCoombe SG, Short RV. Potential HIV-1 target cells in the human penis. AIDS (2006) 20(11):1491-5. doi:10.1097/01.aids.0000237364.11123.98

19. Kardava L, Moir S, Shah N, Wang W, Wilson R, Buckner CM, et al. Abnormal $\mathrm{B}$ cell memory subsets dominate HIV-specific responses in infected individuals. J Clin Invest (2014) 124(7):3252-62. doi:10.1172/JCI74351

20. Wilson TJ, Fuchs A, Colonna M. Cutting edge: human FCRL4 and FcRL5 are receptors for IgA and IgG. J Immunol (2012) 188(10):4741-5. doi:10.4049/ jimmunol.1102651

21. Tarlinton D, Good-Jacobson K. Diversity among memory B cells: origin, consequences, and utility. Science (2013) 341(6151):1205-11. doi:10.1126/ science. 1241146

22. Dement-Brown J, Newton CS, Ise T, Damdinsuren B, Nagata S, Tolnay M. Fc receptor-like 5 promotes B cell proliferation and drives the development of cells displaying switched isotypes. J Leukoc Biol (2012) 91(1):59-67. doi:10.1189/jlb.0211096

23. Sennepin A, Baychelier F, Guihot A, Nel I, Fang RHT, Calin R, et al. NKp44L expression on $\mathrm{CD} 4+\mathrm{T}$ cells is associated with impaired immunological recovery in HIV-infected patients under highly active antiretroviral therapy. AIDS (2013) 27(12):1857-66.

24. Thome JJC, Farber DL. Emerging concepts in tissue-resident T cells: lessons from humans. Trends Immunol (2015) 36(7):428-35. doi:10.1016/j. it.2015.05.003

25. Hoe E, Anderson J, Nathanielsz J, Toh ZQ, Marimla R, Balloch A, et al. The contrasting roles of Th17 immunity in human health and disease: Th17 immunity in health and disease. Microbiol Immunol (2017) 61(2):49-56. doi:10.1111/1348-0421.12471

26. Eyerich K, Dimartino V, Cavani A. IL-17 and IL-22 in immunity: driving protection and pathology. Eur J Immunol (2017) 47(4):607-14. doi:10.1002/ eji.201646723

27. Farag SS, Caligiuri MA. Human natural killer cell development and biology. Blood Rev (2006) 20(3):123-37. doi:10.1016/j.blre.2005.10.001

28. Cua DJ, Tato CM. Innate IL-17-producing cells: the sentinels of the immune system. Nat Rev Immunol (2010) 10(7):479-89. doi:10.1038/nri2800

29. Prodger JL, Gray R, Kigozi G, Nalugoda F, Galiwango R, Hirbod T, et al. Foreskin T-cell subsets differ substantially from blood with respect to HIV co-receptor expression, inflammatory profile, and memory status. Mucosal Immunol (2012) 5(2):121-8. doi:10.1038/mi.2011.56

30. Zhou Z, Xu L, Sennepin A, Federici C, Ganor Y, Tudor D, et al. The HIV-1 viral synapse signals human foreskin keratinocytes to secrete thymic stromal lymphopoietin facilitating HIV-1 foreskin entry. Mucosal Immunol (2017). doi:10.1038/mi.2017.23

31. Pauli NT, Henry Dunand CJ, Wilson PC. Exploiting human memory B cell heterogeneity for improved vaccine efficacy. Front Immunol (2011) 2:77. doi:10.3389/fimmu.2011.00077

32. Moir S, Ho J, Malaspina A, Wang W, DiPoto AC, O’Shea MA, et al. Evidence for HIV-associated B cell exhaustion in a dysfunctional memory B cell compartment in HIV-infected viremic individuals. J Exp Med (2008) 205(8):1797-805. doi:10.1084/jem.20072683

33. Ehrhardt GR, Davis RS, Hsu JT, Leu C-M, Ehrhardt A, Cooper MD. The inhibitory potential of Fc receptor homolog 4 on memory B cells Proc Natl Acad Sci U S A (2003) 100(23):13489-94. doi:10.1073/pnas. 1935944100

34. Brandtzaeg P. Mucosal immunity: induction, dissemination, and effector functions. Scand J Immunol (2009) 70(6):505-15. doi:10.1111/j.1365-3083. 2009.02319.x 
35. Lemos MP, Karuna ST, Mize GJ, Fong Y, Montano SM, Ganoza C, et al. In men at risk of HIV infection, IgM, IgG1, IgG3, and IgA reach the human foreskin epidermis. Mucosal Immunol (2016) 9(3):798-808. doi:10.1038/ mi.2015.103

36. Rath T, Kuo TT, Baker K, Qiao S-W, Kobayashi K, Yoshida M, et al. The immunologic functions of the neonatal Fc receptor for IgG. J Clin Immunol (2013) 33(S1):9-17. doi:10.1007/s10875-012-9768-y

37. Ito T, Carson WF, Cavassani KA, Connett JM, Kunkel SL. CCR6 as a mediator of immunity in the lung and gut. Exp Cell Res (2011) 317(5):613-9. doi:10.1016/j.yexcr.2010.12.018

38. Cha H-R, Ko H-J, Kim E-D, Chang S-Y, Seo S-U, Cuburu N, et al. Mucosa-associated epithelial chemokine/CCL28 expression in the uterus attracts CCR10+ IgA plasma cells following mucosal vaccination via estrogen control. J Immunol (2011) 187(6):3044-52. doi:10.4049/jimmunol.1100402

39. Nguyen PV, Kafka JK, Ferreira VH, Roth K, Kaushic C. Innate and adaptive immune responses in male and female reproductive tracts in homeostasis and following HIV infection. Cell Mol Immunol (2014) 11(5):410-27. doi: $10.1038 / \mathrm{cmi} .2014 .41$

40. Posavad CM, Zhao L, Dong L, Jin L, Stevens CE, Magaret AS, et al. Enrichment of herpes simplex virus type 2 (HSV-2) reactive mucosal T cells in the human female genital tract. Mucosal Immunol (2017) 10(5):1259-69. doi:10.1038/ mi.2016.118

41. Turner DL, Farber DL. Mucosal resident memory CD4 T cells in protection and immunopathology. Front Immunol (2014) 5:331. doi:10.3389/fimmu. 2014.00331

42. Sheth PM, Chege D, Shin LYY, Huibner S, Yue F-Y, Loutfy M, et al. Immune reconstitution in the sigmoid colon after long-term HIV therapy. Mucosal Immunol (2008) 1(5):382-8. doi:10.1038/mi.2008.23

43. Kim CJ, Nazli A, Rojas OL, Chege D, Alidina Z, Huibner S, et al. A role for mucosal IL-22 production and Th22 cells in HIV-associated mucosal immunopathogenesis. Mucosal Immunol (2012) 5(6):670-80. doi:10.1038/ mi.2012.72

44. Shanmugasundaram U, Critchfield JW, Pannell J, Perry J, Giudice LC, Smith-McCune K, et al. Phenotype and Functionality of $\mathrm{CD} 4{ }^{+}$and CD8 ${ }^{+}$ $\mathrm{T}$ cells in the upper reproductive tract of healthy premenopausal women. Am J Reprod Immunol (2014) 71(2):95-108. doi:10.1111/aji.12182

45. Golubovskaya V, Wu L. Different subsets of T cells, memory, effector functions, and CAR-T immunotherapy. Cancers (2016) 8(3):36. doi:10.3390/ cancers 8030036

46. Kiravu A, Gumbi P, Mkhize NN, Olivier A, Denny L, Passmore J-A. Evaluation of CD103 ( $\alpha \mathrm{E} \beta 7$ ) integrin expression by CD8 T cells in blood as a surrogate marker to predict cervical $\mathrm{T}$ cell responses in the female genital tract during HIV infection. Clin Immunol (2011) 141(2):143-51. doi:10.1016/j. clim.2011.06.008

47. Briceño O, Pinto-Cardoso S, Rodríguez-Bernabe N, Murakami-Ogasawara A, Reyes-Terán G. Gut homing CD4+ and CD8+ T-cell frequencies in HIV infected individuals on antiretroviral treatment. PLoS One (2016) 11(11): e0166496. doi:10.1371/journal.pone.0166496

48. Xia M, Hu S, Fu Y, Jin W, Yi Q, Matsui Y, et al. CCR10 regulates balanced maintenance and function of resident regulatory and effector $\mathrm{T}$ cells to promote immune homeostasis in the skin. J Allergy Clin Immunol (2014) 134(3):634-44.e. doi:10.1016/j.jaci.2014.03.010

49. Nagakubo D, Yoshie O, Hirata T. Upregulated CCL28 expression in the nasal mucosa in experimental allergic rhinitis: Implication for CD4+ memory T cell recruitment. Cell Immunol (2016) 302:58-62. doi:10.1016/j.cellimm. 2016.02.001

50. Iwasaki A. Antiviral immune responses in the genital tract: clues for vaccines. Nat Rev Immunol (2010) 10(10):699-711. doi:10.1038/nri2836

51. Cheeseman HM, Carias AM, Evans AB, Olejniczak NJ, Ziprin P, King DFL, et al. Expression profile of human Fc receptors in mucosal tissue: implications for antibody-dependent cellular effector functions targeting HIV-1 transmission. PLoS One (2016) 11(5):e0154656. doi:10.1371/journal.pone. 0154656

52. Carrega P, Morandi B, Costa R, Frumento G, Forte G, Altavilla G, et al. Natural killer cells infiltrating human nonsmall-cell lung cancer are enriched in CD56brightCD16- cells and display an impaired capability to kill tumor cells. Cancer (2008) 112(4):863-75. doi:10.1002/cncr.23239

53. León F, Roldán E, Sanchez L, Camarero C, Bootello A, Roy G. Human small-intestinal epithelium contains functional natural killer lymphocytes. Gastroenterology (2003) 125(2):345-56. doi:10.1016/S0016-5085(03) 00886-2

54. Mselle TF, Meadows SK, Eriksson M, Smith JM, Shen L, Wira CR, et al. Unique characteristics of NK cells throughout the human female reproductive tract. Clin Immunol (2007) 124(1):69-76. doi:10.1016/j.clim.2007.04.008

55. Takayama T, Kamada N, Chinen H, Okamoto S, Kitazume MT, Chang J, et al. Imbalance of NKp44+NKp46- and NKp44-NKp46+ natural killer cells in the intestinal mucosa of patients with Crohn's disease. Gastroenterology (2010) 139(3):882-92.e. doi:10.1053/j.gastro.2010.05.040

56. Colonna M. Interleukin-22-producing natural killer cells and lymphoid tissue inducer-like cells in mucosal immunity. Immunity (2009) 31(1):15-23. doi:10.1016/j.immuni.2009.06.008

57. Lee SK, Kim CJ, Kim D-J, Kang J. Immune cells in the female reproductive tract. Immune Netw (2015) 15(1):16. doi:10.4110/in.2015.15.1.16

58. Buckner CM, Moir S, Kardava L, Ho J, Santich BH, Kim LJY, et al. CXCR4/ IgG-expressing plasma cells are associated with human gastrointestinal tissue inflammation. J Allergy Clin Immunol (2014) 133(6):1676-85.e. doi:10.1016/j. jaci.2013.10.050

Conflict of Interest Statement: The authors declare that the research was conducted in the absence of any commercial or financial relationships that could be construed as a potential conflict of interest.

Copyright (c) 2017 Sennepin, Real, Duvivier, Ganor, Henry, Damotte, Revol, Cristofari and Bomsel. This is an open-access article distributed under the terms of the Creative Commons Attribution License (CC BY). The use, distribution or reproduction in other forums is permitted, provided the original author(s) or licensor are credited and that the original publication in this journal is cited, in accordance with accepted academic practice. No use, distribution or reproduction is permitted which does not comply with these terms. 